\title{
Exploiting Endocytosis for Nanomedicines
}

\author{
Akin Akinc ${ }^{1}$ and Giuseppe Battaglia ${ }^{2,3}$ \\ ${ }^{1}$ Alnylam Pharmaceuticals, Cambridge, Massachusetts 02142 \\ ${ }^{2}$ Department of Chemistry, University College London, London WC1H 0AJ, United Kingdom \\ ${ }^{3}$ MRC Centre for Medical Molecular Virology, University College London, London WC1E 6BT, United Kingdom \\ Correspondence: aakinc@alnylam.com; g.battaglia@ucl.ac.uk
}

In this article, we briefly review the endocytic pathways used by cells, pointing out their defining characteristics and highlighting physical limitations that may direct the internalization of nanoparticles to a subset of these pathways. A more detailed description of these pathways is presented in the literature. We then focus on the endocytosis of nanomedicines and present how various nanomaterial parameters impact these endocytic processes. This topic is an area of active research, motivated by the recognition that an improved understanding of how nanomaterials interact at the molecular, cellular, and whole-organism level will lead to the design of better nanomedicines in the future. Next, we briefly review some of the important nanomedicines already on the market or in clinical development that serve to exemplify how endocytosis can be exploited for medical benefit. Finally, we present some key unanswered questions and remaining challenges to be addressed by the field.

$\mathrm{N}$ anomedicines are increasingly becoming a part of our medical armament to diagnose and treat disease. The term "nanomedicine" often refers to the use of various nanotechnology strategies for medical applications. Inherent in this concept is the recognition that nanosized features offer certain advantageous properties, and one of the most widely exploited of these properties is the ability to gain cellular entry through endocytosis. Endocytosis has an important role in diagnostics, allowing for the selective uptake and labeling of cells by various medical imaging agents (e.g., as contrast agents for identifying cancerous lesions by MRI). However, it has an even larger role in therapeutics, where it offers a means for active cellular uptake of drugs. In some applications, endocy- tosis is exploited to improve drug pharmacology by increasing selectivity, for example, through particle properties that restrict cellular uptake to phagocytic cells, targeted delivery via receptor-mediated endocytosis, or prodrug approaches that require cellular uptake and lysosomal processing for drug activation. Increased target selectivity leads to improved potency and/or decreased toxicity, resulting in an overall improved therapeutic index. In other applications, endocytosis is exploited to fundamentally enable drug activity. Endocytosis provides a means of cellular uptake for compounds that require intracellular delivery for their mechanism of action, but that otherwise cannot enter cells by passive diffusion (e.g., plasmid DNA, antisense oligonucleotides [ASOs], small inter-

Editors: Sandra L. Schmid, Alexander Sorkin, and Marino Zerial

Additional Perspectives on Endocytosis available at www.cshperspectives.org

Copyright (C) 2013 Cold Spring Harbor Laboratory Press; all rights reserved; doi: 10.1101/cshperspect.a016980

Cite this article as Cold Spring Harb Perspect Biol 2013;5:a016980 
fering RNAs [siRNAs], and certain proteins and oligopeptides). In many ways, endocytosis is an ideal process for delivering nanomedicines because it is the natural process by which material and information are transported between and within cells. It is no surprise that endocytic processes often serve to inform and guide the design of novel nanomedicines.

\section{PARAMETERS AFFECTING NANOMEDICINE ENDOCYTOSIS}

Cell entry is strictly controlled at the plasma membrane. At a molecular level, small compounds soluble within the lipid membrane can easily diffuse across passively, whereas polar molecules need active, energy-dependent processes to cross the membrane. This is either achieved by protein transporters lodged within the membrane or by inducing membrane remodeling that drives the formation of membrane-enclosed sacs known as vesicles. These can be as large as micrometers or as small as 10 s of nanometers, and they form from "pinching off" segments of the membrane of origin. In such a way, material is continuously exchanged between the extracellular space and the cell interior (e.g., cytosol) via endocytosis (in) and exocytosis (out) (Gruenberg 2001; Doherty and McMahon 2009; Kumari et al. 2010; Canton and Battaglia 2012). As shown in Figure 1, endocytosis governs the intake of whole cells, viruses, and proteins. Some of these "cytonauts" are endogenous in nature and essential for cellular homeostasis, whereas others are exogenous and pathogenic and require entry for opportunistic reasons. Without going into the details of each pathway, which are described elsewhere in this collection, endocytosis can be separated into two fundamental steps: (1) binding and subsequent membrane deformation, and (2) intracellular sorting. Interestingly, eukaryotic cells can control these steps to ingest materials over four orders of magnitude in size; however, the majority of materials internalized are well within nanotechnology remits (i.e., submicron). A key question is how to extract and use an understanding of endocytosis to guide the design of nanomedicines that can exploit endocytosis to gain entry into cells.
On the basis of their constitutive bonds, traditional nanoparticles can be classified into two categories: those formed via strong interactions such as ionic, metallic, and covalent bonds (e.g., quantum dots, gold nanoparticles, and carbon nanotubes) and those formed via weak interactions such as hydrogen bonds, hydrophobic effects, columbic forces, and their combination (e.g., supramolecular gels, cyclodextrin, micelles, and vesicles). Both "hard" and "soft" nanoparticles have an intrinsic large surface area, and thus interfacial forces dominate most of their surroundings. Although hard nanoparticles have a defined solid-liquid interface, soft nanoparticles are characterized by a dynamic liquid-liquid interface (Dagastine et al. 2006). This difference is critical for understanding nanoparticle/biological interactions and, more importantly, for how the nanoparticle interface exchanges materials with the surroundings. For example, soft nanoparticles are more fragile but have surface energies with orders of magnitude similar to those of biological surfaces. On the other hand, hard nanoparticles are more robust but have much higher surface tensions, such that they may induce surface catalytic events that could lead to adverse outcomes (Nel et al. 2009). Hard or soft, from an engineering point of view, we have today the ability to form a large variety of nanosystems, controlling surface chemistry, size, shape, surface topology, and mechanical properties with molecular precision. When it comes to the design of nanomedicines, it is thus important to understand how such structural parameters are associated with specific biological functions and, in particular, endocytosis.

\section{Surface Chemistry}

Simply classifying internalization of nanoparticles in terms of their surface charge, neutral and anionic nanoparticles are internalized considerably less efficiently than cationic ones (Miller et al. 1998; Blanazs et al. 2009; Cho et al. 2009; Asati et al. 2010; Lin et al. 2010). Kannan and colleagues observed anionic nanoparticles entered via a caveolae-mediated route, whereas both neutral and cationic nanoparticles entered 
Exploiting Endocytosis for Nanomedicines
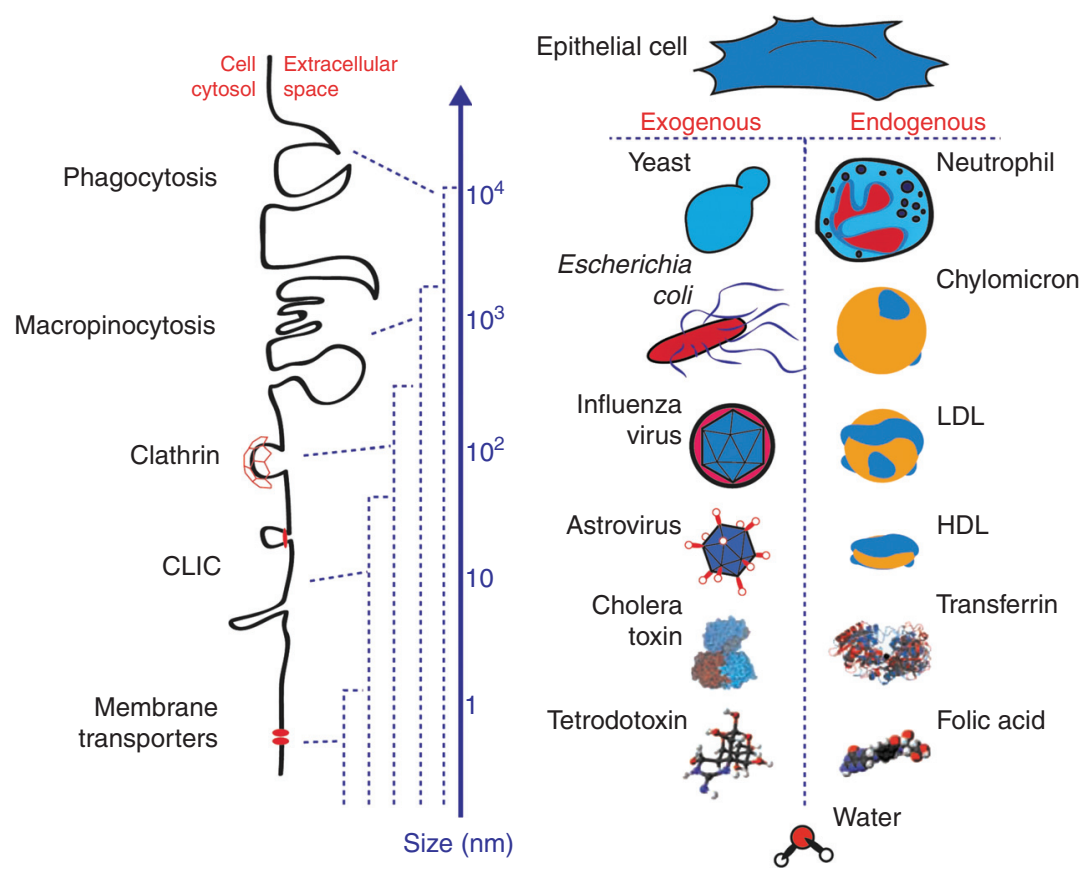

Figure 1. Mechanisms of endocytosis and their relationship with size of either endogenous or exogenous cargo.

via nonclathrin- and noncaveolae-mediated mechanisms (Perumal et al. 2008). This is due to the high affinity of cationic species to negatively charged proteoglycans expressed on the surface of most cells (Mislick and Baldeschwieler 1996). However, it is important to point out that most cationic systems have also been reported to be cytotoxic (Moghimi and Patel 2002; Moghimi et al. 2005; Symonds et al. 2005; Xia et al. 2006, 2008; Hunter and Moghimi 2010). For example, Blanazs et al. (2009) observed rapid internalization using cationic poly(2-[dimethylamino] ethyl methacrylate) (PDMA) polymersomes; however, long-term exposure showed a considerable decrease in uptake, which was due to the toxic effect of the cationic polymer on cells. Anionic particles may have fewer-reported toxic effects, but their strong interaction with proteins (including immunemodulating proteins) hinders their translation into many biomedical applications (Vonarbourg et al. 2006). Indeed, the very first requisite for an optimal surface chemistry is that the nanoparticle stay dispersed in biological media. This is a crucial and often overlooked parameter.
Several in vitro studies have shown that cellular uptake is strongly affected by how nanoparticles aggregate in cell culture media (Lesniak et al. 2010; Maiorano et al. 2010; Qiu et al. 2010; Rausch et al. 2010; Albanese and Chan 2011). The association of proteins with device surfaces is a critical parameter in the design of medical devices and hence has been the subject of several studies (Wahlgren and Arnebrant 1991; Ramsden 1994). Surface adsorption can alter protein structure, exposing segments normally buried in the native protein conformation, thus modifying signaling (Lynch et al. 2006) and, in some cases, causing fibrillation (Linse et al. 2007). Proteins can form a corona that can quickly cover the entire nanoparticle surface, even at low plasma concentrations (Lundqvist et al. 2011; Monopoli et al. 2011). An effective approach to limit protein fouling is to coat the surface with a polymer brush layer that generates repulsive steric forces (Leckband and Israelachvili 2001). Both nonionic and zwitterionic watersoluble polymers fit these conditions. These include poly(ethylene oxide) (PEO), also known as poly(ethylene glycol) (PEG) (Alcantar et al. 
2000; Harris and Chess 2003), dextran (Lemarchand et al. 2004), poly(N-vinyl pyrrolidone) (PVP) (Francois et al. 1996; Huang et al. 2010), poly(vinyl alcohol) (PVA) (Barrett et al. 2001), poly(2-methyl-2-oxazoline) (PMOXA) (Zalipsky et al. 1996; Konradi et al. 2008), poly(2-ethyl-2-oxazoline) (PEOXA) (Zalipsky et al. 1996), poly (2-methacryloyloxyethyl phosphorylcholine) (PMPC) (Ishihara et al. 1999; Lewis 2000), and poly(sulfobetaine methacrylate) (PSBMA) (Kitano et al. 2010). However, when it comes to biomedical applications, the material has also to be tested for immunogenicity (Vonarbourg et al. 2006). Today, the gold standard in coating for biomedical applications is PEO, with PVP, PMPC, and PMOXA being proposed as valid alternatives (Chen et al. 2010). PEGylation, that is, the attachment of PEO chains, has been used for many years as a strategy to prevent protein adsorption onto nanoparticles and to facilitate long circulation times in biological fluids (particularly blood) (Alcantar et al. 2000; Harris and Chess 2003). The inhibition of unspecific cellular internalization, often using PEO coating, is critical for the design of specifically targeted nanoparticles. Nanoparticle targeting is normally achieved by decorating the particles with moieties that should bind preferentially to specific cells. Nevertheless, this is strongly dependent on the identification of cellular/tissue-specific markers. Cellular specificity combined with endocytosis ensures that once the nanoparticle reaches its target, it is readily internalized. For this reason, very often the receptor of choice is associated with endocytosis, such as transferrin receptors (Tanaka et al. 2001; Iinuma et al. 2002), EGF receptors (Kirpotin et al. 2006; Zeng et al. 2006; Lee et al. 2007; Mi et al. 2013), albumin receptors (Schmid et al. 2007; Kratz 2008), folate receptors (Lee and Low 1994; Pan et al. 2002; Zhang et al. 2007; Han et al. 2009), and LDL receptors (Chnari et al. 2006), to name a few.

\section{Size}

Some entry mechanisms are very specific when it comes to acceptable cargo size, whereas others are less so. For example, phagocytosis has been believed for quite some time to be associated uniquely with the uptake of large particles $(>1 \mu \mathrm{m})$. However, there are several reports that show the phagocytosis of nanometer-sized particles such as viruses (Clement et al. 2006; Ghigo et al. 2008), gold (Krpetic et al. 2010; Franca et al. 2011), silver (Park et al. 2011), and polymer nanoparticles (Lunov et al. 2011), as well as quantum dots (Fischer et al. 2010). Most of these studies have also shown that changes to nanoparticle size do not affect their phagocytosis. Nevertheless, it is worth noting that this endocytic mechanism is strongly linked to protein opsonization, which can induce aggregation and hence a loss in size control. Similarly, macropinocytosis can be exploited for the uptake of large particles (up to $1 \mu \mathrm{m}$ ) (Swanson 2008). However, because macropinocytosis is a cargo-unspecific uptake mechanism, it can accommodate a range of cargo sizes and types of materials and often operates in conjunction with other entry mechanisms (Rejman et al. 2004; Corsi et al. 2009; Nam et al. 2009; Thurn et al. 2011). Eukaryotic cells can use clathrinmediated entry to internalize particles with sizes ranging from $10 \mathrm{~nm}$ to as high as $300 \mathrm{~nm}$ (Heuser and Reese 1973; Wasylewski et al. 1986; Ehrlich et al. 2004). For caveolin-mediated endocytosis, already formed caveolae have diameters $\sim 50-80 \mathrm{~nm}$ with a neck $\sim 20-40 \mathrm{~nm}$ (Rothberg et al. 1992; Anderson 1998; Kurzchalia and Parton 1999; Pelkmans and Helenius 2002). Even though this would suggest a tight limit for cargo size, Wang et al. (2009) have observed that this route can facilitate the entry of nanoparticles up to $100 \mathrm{~nm}$ in diameter. As for the other clathrin-independent entry routes, the data so far seem to suggest that these mechanisms would hinder the uptake of particles larger than $100 \mathrm{~nm}$ (Mayor and Pagano 2007). Recently, a flotillin-mediated endocytosis mechanism has been proposed for the entry of different sized disulfide-based poly(amidoamine)/ DNA polyplexes (Vercauteren et al. 2011). It is important to note that most of the entry mechanisms can be assumed to operate simultaneously, making it very difficult to identify a specific one. The use of experimental approaches based on arrays of inhibitors for specific path- 
Exploiting Endocytosis for Nanomedicines

ways is often complicated; inhibitors can promote toxicity and artifacts, and they need adequate controls, which are often overlooked (Vercauteren et al. 2010).

Nanoparticles can induce deformation and even complete invagination as a consequence of physical interactions with lipid membranes. The simple attractive interaction between the curved surface of the nanoparticle and the cell membrane produces the necessary deformation to drive nanoparticle engulfment (Lipowsky and Dobereiner 1998; Deserno 2004). This process depends both on the adhesion forces between membranes and nanoparticles and on membrane rigidity, which together set a specific critical radius for the nanoparticle to be internalized. This approach can be further enhanced including more specific receptor-mediated interactions (Tzlil et al. 2004; Gao et al. 2005; Zhang et al. 2009; Yuan et al. 2010; Chaudhuri et al. 2011; Yi et al. 2011). All of the models converge at the same conclusion, that the particles ought to have a minimum radius between
20 and $30 \mathrm{~nm}$ to achieve effective cellular uptake (Tzlil et al. 2004; Gao et al. 2005; Zhang et al. 2009; Yuan et al. 2010; Chaudhuri et al. 2011; Yi et al. 2011). As shown by the phase diagram in Figure 2A, the efficiency of cellular uptake depends on both the size and ligand density of the nanoparticle (Yuan et al. 2010). Experimental evidence has supported these theoretical models. Aoyama and coworkers showed that calix [4]-resorcarene-based macrocyclic glycocluster amphiphiles complexed to DNA-transfected cells as a function of their size, with 25-nm-radius particles entering cells more effectively than 50-nm-radius particles, and even more so than 100-nm-radius particles (Nakai et al. 2003). The same group showed, using the same chemistry to coat quantum dots, that particles of $25 \mathrm{~nm}$ radius entered cells more effectively than particles of $7.5 \mathrm{~nm}$ radius, and even more so than particles of $2.5 \mathrm{~nm}$ radius, suggesting an optimal radius at $\sim 25 \mathrm{~nm}$ (Nakai et al. 2003). Chan and coworkers unified the two ranges by studying the internalization of pristine (Chithrani
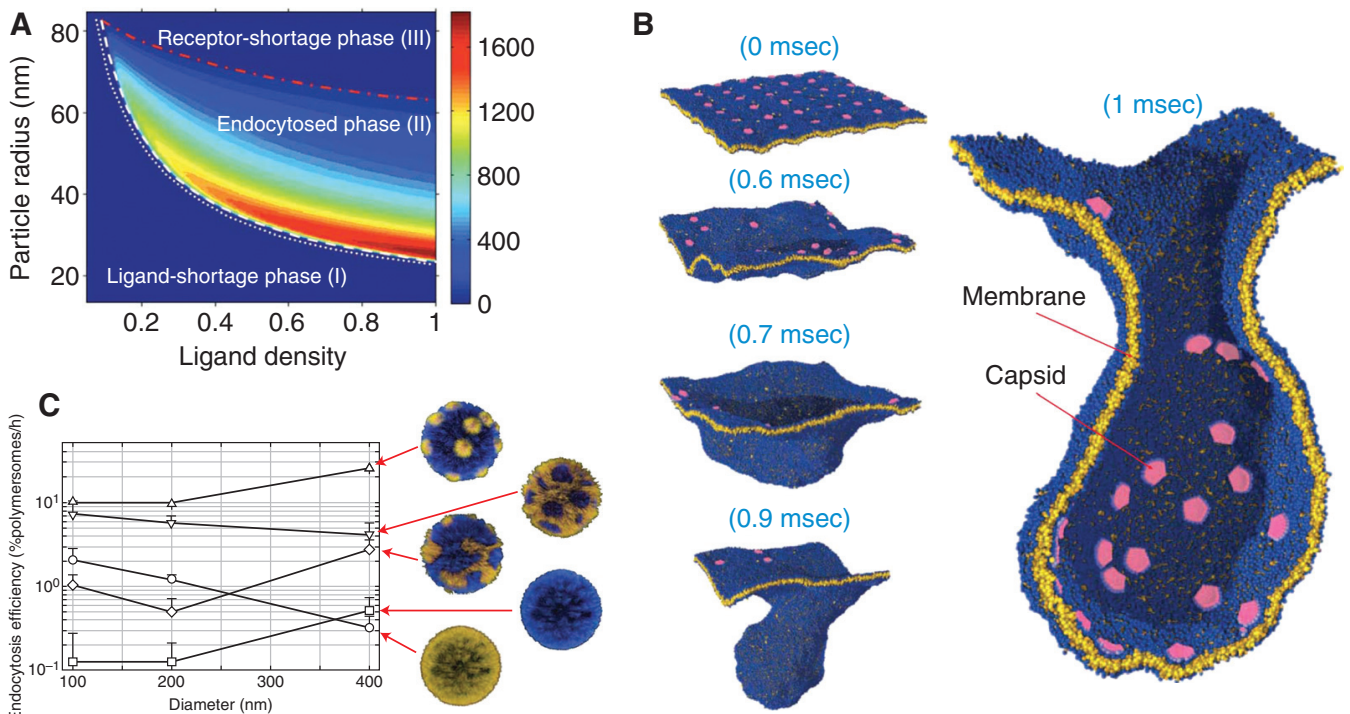

Figure 2. (A) A two-dimensional (2D) phase diagram on the nanoparticle radius ligand density plane characterizes the interrelated effects of particle size and ligand density on the cellular uptake. (From Yuan et al. 2010; adapted, with permission, from the American Physical Society (C) 2010.) (B) Coarse-grained simulations of curvature-inducing proteins bound on membranes at different times show that a membrane-bound protein cluster drives the formation of vesicles whose size is controlled by the local curvature uptake. (From Reynwar et al. 2007; adapted, with permission, from the Nature Publishing Group (C) 2010.) (C) Endocytosis efficiency as a function of the polymersome diameter for different patchy cell-active (gold) and cell-inert (blue) nanoparticles. 
et al. 2006) and protein-coated gold nanoparticles (Chithrani and Chan 2007) with size ranging from a few to hundreds of nanometers in different cell types, showing 20-25 nm to be the optimal radius for uptake (Chithrani et al. 2006; Jiang et al. 2008). Although the theoretical and experimental studies agree on optimal size (20$30 \mathrm{~nm}$ of radius), most models suggest a threshold radius below which there cannot be cellular uptake, and a consequent asymmetric distribution of the uptake, which decays with particle size. Clearly, the real scenario is more complex, often involving several pathways, some of which are independent of size (e.g., macropinocytosis). It is worth pointing out that the most effective nanoscopic vector to exploit endocytosis (the virus) does not come in one size. Virus diameters range from $\sim 30 \mathrm{~nm}$ for parvoviruses to $400 \mathrm{~nm}$ for poxviruses, with the majority of the viruses having diameters between 60 and $150 \mathrm{~nm}$ (Dimitrov 2004; Marsh and Helenius 2006; Mercer et al. 2010). Although perfectly within the nanotechnology remits, this range is slightly broader than the optimal diameter proposed by both experiments and theoretical models discussed above. This suggests that size alone does not determine endocytosis and several other parameters have an important role.

\section{Shape}

When it comes to cellular interactions, nanoparticle shape is as important as nanoparticle size. Champion and Mitragotri (2006) have shown this very elegantly by incubating macrophages with polystyrene microparticles with different shapes. They observed that the local shape controls how fast cells internalize particles. When the particle has too large a surface area, the macrophage fails to internalize the particle and simply spreads around it (Champion and Mitragotri 2006). More importantly, this phenomenon occurs independently of the particle size and whether it is opsonized or not, emphasizing even more the shape effect (Champion and $\mathrm{Mi}$ tragotri 2006). Chan and coworkers observed that cylindrical gold nanoparticles were internalized by HeLa cells less efficiently than spherical ones, again regardless of whether these were functionalized or not with transferrin (Chithrani et al. 2006; Chithrani and Chan 2007). Qiu et al. (2010) also studied the aspect ratio effects on cellular internalization of gold nanorods, concluding that surface chemistry, rather than surface area, had a dominant role over shape, because cationic gold nanorods exhibited a much greater ability to enter cells. Jin and coworkers performed similar experiments using single wall carbon nanotubes. They showed that the cellular uptake trend was bell-shaped as a function of the tube length, with $320 \mathrm{~nm}$ being the optimal length corresponding to an effective capture radius of $26.4 \mathrm{~nm}$ (Jin et al. 2009). Hutter et al. (2010) showed the uptake of gold nanometer spheres, rods, and spiky nanoparticles by two types of CNS-associated cells-one phagocytic (microglia cells) and one nonphagocytic (neurons). They observed that spiky nanoparticles are preferentially taken up by microglia, but only rods are internalized by neurons, suggesting that cells display selectivity toward certain particle shapes by favoring phagocytosis or not (Hutter et al. 2010). DeSimone and coworkers developed a method (Rolland et al. 2005; Perry et al. 2011) called PRINT ( particle replication in nonwetting templates) to form cross-linked poly(ethylene glycol) hydrogels with different shapes. They then studied how the morphology affected cell internalization (Gratton et al. 2008), observing that both size as well as the aspect ratio of cylindrical particles had a considerable effect on the cellular uptake. Recently, Barua et al. (2013) have observed that cylindrical nanoparticles coated with monoclonal antibodies targeting human epidermal growth factor receptor 2 (HER2) have higher specific cellular uptake and lower unspecific uptake when compared with their spherical equivalent, suggesting a strong relationship between shape and molecular recognition.

\section{Surface Topology}

It is now appreciated that membrane signaling and trafficking are not only controlled by relative receptor expression but also by their topological arrangement (Lingwood and Simons 2010). In recent years, advanced microscopy techniques 
Exploiting Endocytosis for Nanomedicines

have enabled the mapping of similar patterns in smaller structures including biological transporters such as viruses, synaptic vesicles, lipoproteins, and bacteria. In these, key ligands can have a topology that can be ordered, such as in most naked viruses (Dimitrov 2004); semiordered, such as in lipoproteins (Ren et al. 2010); or disordered with typical Turing-like arrangement, such as in most enveloped viruses (Grunewald et al. 2003) and endogenous trafficking vesicles (Takamori et al. 2006). Surface topology is not stochastic and is the result of an evolutionary drive often associated with a specific function. Viruses, for example, change their surface topology during maturation from a noninfectious, almost inert assembly, to an infectious cell-active machinery (Veesler and Johnson 2012). It is therefore not farfetched to hypothesize that viruses as well as endogenous lipoproteins and trafficking vesicles have surface topology matching that of the cell surface they target. This would suggest that cellular targeting and signaling are not only controlled at a molecular level (i.e., ligand/receptor interaction) but also at a mesoscale level (i.e., how the ligand/ receptor are organized). Endocytosis, in particular, requires the remodeling of large segments of the cell membrane via accessory proteins that can induce and sense membrane curvature (McMahon and Gallop 2005; Zimmerberg and Kozlov 2006; Frost et al. 2009). Deserno and colleagues have observed by coarse-grained simulations that curvature-inducing proteins bound on membranes can attract each other as a result of membrane curvature. The consequent membrane-bound protein cluster drives the formation of vesicles whose size is controlled by the local curvature and is considerably larger than the single proteins (Fig. 3B) (Reynwar et al. 2007). Recently, surface topology has also been integrated in nanoparticle design, and a few preliminary studies have started unveiling the importance of topology on endocytosis. Verma et al. (2008) have observed that gold nanoparticles coated with different self-assembled monolayers of organic ligands enter cells depending on their surface topology. They have shown that nanoparticles with subnanometer striations of alternating anionic and hydrophobic groups can enter cells via membrane poration, whereas nanoparticles with the same chemistry but coated with a random distribution enter cells via an endocytic route (Verma et al. 2008). At a different scale, the Battaglia group has recently shown

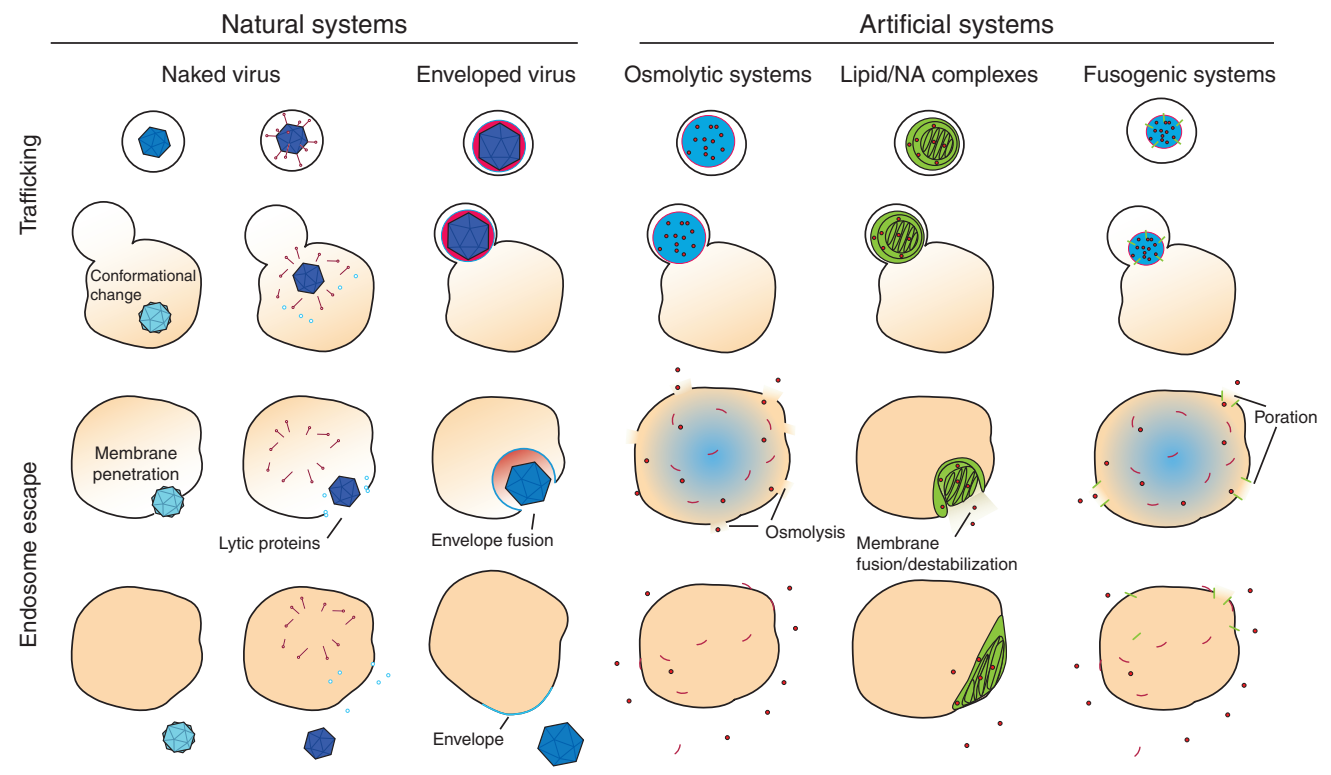

Figure 3. Mechanism of viral and artificial system endosomal escape. 
the possibility to form nanoparticles with different surface topologies (Massignani et al. 2009; LoPresti et al. 2011) using cell-inert and cellactive polymer domains. Nanoparticles form with either patchy or striated surface patterns (see Fig. 2C). As shown in the graph in Figure $2 \mathrm{C}$, the internalization of the patchy particles is considerably different from the pure formulations. Patchy particles with discrete domains showed substantially higher endocytosis efficiencies compared with the pure formulations across all diameters (Massignani et al. 2009; LoPresti et al. 2011). More interestingly, the size effect that characterizes the pristine formulation is no longer relevant, with the patchy formulations showing a slight increase in uptake as a function of size (Massignani et al. 2009; LoPresti et al. 2011). Such results show how surface topology has a quite drastic effect on cell endocytosis, possibly explaining why enveloped viruses have strong infection capability even though they come in a relatively large variety of sizes (Harris et al. 2006).

\section{Endosome Escape Strategies}

Bioactive cargoes that are intended to have pharmacological action inside the cell need to escape from the degradative environment of the endocytic organelles. Many proteins, nucleic acids, and even some small-molecule drugs fall into this category. Escaping the endolysosomal pathway in not an easy task because it is an integral part of the metabolic and catabolic network of the cell, and thus its disruption (even temporary) is often associated with cellular stress. Unless the final objective is to selectively kill the targeted cell (e.g., cancer therapy), it is paramount to devise strategies to escape from the endocytic pathway in an effective, yet relatively harmless, manner. Natural pathogens such as viruses and bacteria use endocytosis as a portal to the cell. This has created an evolutionary race between pathogens to create new escape mechanisms and their hosts to create new ways to prevent and/or detect these escape mechanisms (Gruenberg and van der Goot 2006; Mercer et al. 2010). Many bacteria can enter cells and some can even escape into the cytosol from the corresponding endocytic organelle (Ray et al. 2009). This is often achieved by the release of pore-forming proteins and phospholipases that intentionally disrupt the organelle membrane (Ray et al. 2009). As shown in Figure 3, depending on whether viruses are enveloped or naked, they adopt different strategies to deliver their genetic cargo into the cell interior (Mercer et al. 2010; Vazquez-Calvo et al. 2012). Naked viruses, that is, viruses lacking a phospholipid envelope, enter the cytosol through the formation of pores in the endosomal membrane. This is either achieved by exposing hydrophobic residues that favor membrane association and penetration (Tsai 2007) or via the release of lytic amphipathic proteins that interact with the endosome membrane in a $\mathrm{pH}$-controlled manner (Wiethoff et al. 2005). Enveloped viruses have a more efficient approach and make use of their phospholipid envelope to escape endosomes. They use fusion proteins (often $\mathrm{pH}$ controlled) that fuse the viral envelope with the endosomal membrane, enabling the escape of the internal capsid into the cytosol in such a way as to avoid the potentially dangerous release of endosomal contents (Marsh and Helenius 2006; Mercer et al. 2010; Vazquez-Calvo et al. 2012). Nanotechnologists are taking inspiration on these strategies to design cellular delivery vectors. Nanoparticles have been decorated with several natural peptides borrowed either from bacteria (Mastrobattista et al. 2002; Akin et al. 2007) or viruses (Joanne et al. 2009). These include HIVderived HGP-peptide (Kwon et al. 2010), TATfusion peptide (Wadia et al. 2004), influenza virus hemagglutinin HA-2 amino-terminal fusogenic peptide (Wagner et al. 1992), and papillomavirus L240 peptide (Kwon et al. 2008). These natural cell-penetrating peptides have also inspired several synthetic strategies, and several artificial peptides have been proposed to favor cellular delivery (Subbarao et al. 1987; Wyman et al. 1997; Stayton et al. 2000; Jones and Sayers 2012). There is still much unknown about the cell penetration and poration mechanisms of these peptides as well as concerns regarding immunogenicity and cytotoxicity (Jones and Sayers 2012).

One way around the intrinsic immunogenicity of pathogen-derived peptides is to design 
Exploiting Endocytosis for Nanomedicines

synthetic polymers and lipids that enhance endosomal escape. Fusogenic lipids, of which phosphatidylethanolamine $(\mathrm{PE})$ is a common example, show an interesting behavior when dispersed in water. Unlike most membrane-forming lipids that assemble into lamellar phases, these lipids assemble into inverse hexagonal phases (Koltover et al. 1998). Often this self-assembly can be altered by $\mathrm{pH}$, offering the potential for $\mathrm{pH}$-triggered membrane destabilization in the endosome (Caracciolo et al. 2009; Semple et al.2010). Alternative membrane-destabilizing systems have been proposed using fully synthetic polymers such as poly(propylacrylic acid) (PPAA) (Kyriakides et al. 2002; Jones et al. 2003; Kusonwiriyawong et al. 2003; Lee et al. 2006).

Endosomal escape and increased ability of intracellular delivery of nucleic acids have been claimed by many groups using cationic polymers that allow for efficient binding and condensation of nucleic acids via the formation of complexes often referred to as polyplexes (Neu et al. 2005). The cationic nature favors strong cellular interaction and hence internalization; however, their escape mechanism into the cytosol has been the subject of debate. For many years, it has been postulated that once inside the acidic endosomes, the amine groups of these molecules bind to the protons generated by the vacuolar ATPase. This, in turn, slows down the process of acidification, with a consequent increase of the endosomal osmolarity. Such an effect is known as the "proton sponge effect," and it ascribes endolysosomal destabilization via an increase of ionic concentration and subsequent osmotic swelling and rupture (Boussif et al. 1995; Behr 1997; Patil et al. 2009). This principle is shared with many weak bases and, in particular, chloroquine, used quite commonly as an adjuvant for DNA transfection (Behr 1997). Although it is well established that cationic polymers release nucleic acids before reaching the lysosomal compartment (Akinc and Langer 2002; Sonawane et al. 2003), the mechanism of endosomal disruption is still unclear. Godbey et al. (2000) measured endolysosomal pH during cell transfection with PEI/DNA complexes, showing that the normal lysosomal $\mathrm{pH}$ value of
5.0 was not altered. Bieber et al. (2002) investigated whether the membrane destabilization effect is due to a direct binding of the PEI-DNA aggregates to the inner endolysosomal membrane surface. Similarly, Erbacher et al. (1996) have shown no relationship between the neutralization of the acidic compartments and the cytosol delivery efficiency.

A more recent approach based on fully synthetic systems is using controlled conformational changes that drive fast and efficient endosome membrane destabilization. These can be either the $\mathrm{pH}$-induced swelling of nanoparticles $(\mathrm{Hu}$ et al. 2007) or more complex assembly/disassembly transitions. Among the latter, a very attractive platform has been proposed using synthetic vesicles formed by polymers known as polymersomes (Discher and Eisenberg 2002; LoPresti et al. 2009). These synthetic alternatives to lipid vesicles can be designed to undergo controlled disassembly as a function of several external stimuli to release their cargo. Typical examples of release-triggering stimuli are temperature (Qin et al. 2006), light (Robbins et al. 2009), ultrasound and magnetic field (Meng et al. 2009), redox conditions (Cerritelli et al. 2007), enzymatic cleavage (Ahmed and Discher 2004), and, most relevant, pH (Du et al. 2005; Ahmed et al. 2006; Lomas et al. 2008; Qiu et al. 2010). Cerritelli et al. (2007) have shown that using a protease-sensitive sulfur bridge polymersome, cytosolic delivery can be achieved. Similarly Ahmed and coworkers have shown that the endocytic degradative environment can favor cytosolic delivery using hydrolyzable polymersomes (Ahmed et al. 2006; Kim et al. 2009). pH-sensitive polymersomes have also been proposed by the Battaglia group using poly(2-[diisopropylamino] ethyl methacrylate) (PDPA) (Lomas et al. 2007, 2008; Massignani et al. 2010). At physiological pH, PDPA copolymers aggregate to form stable vesicles that can encapsulate several molecules and macromolecules (Lomas et al. 2007, 2008; Massignani et al. 2010). However, the very narrow $\mathrm{pH}$ switch (PDPA $\mathrm{p} K_{a}=6.3$ at physiological condition) guarantees dissociation and endosomal release of the cargo around a comfortable $\mathrm{pH}$ for biological molecule stability, avoiding cytotoxicity 
and cellular stress (Lomas et al. 2008; Hearnden et al. 2009; Massignani et al. 2010). This approach has enabled the delivery of many types of cargos including plasmid DNA, small molecules, antibodies, and small nanoparticles (Lomas et al. 2007, 2008; Massignani et al. 2010; Canton et al. 2013).

\section{NANOMEDICINES OF TODAY EXPLOITING ENDOCYTOSIS}

Although many of the nanomedicines of the future-using designs and strategies to make optimal use of endocytic pathways - are in the early stages of conception and preclinical development, there are numerous nanomedicines of today that exploit endocytosis that are already on the market or in late stages of clinical development. Here we briefly review some of these drugs, leaving aside other important nanomedicines that do not specifically rely on endocytosis for their mechanism of action. For example, several nanomedicines have been designed to accumulate in tumors or sites of inflammation via the enhanced permeation retention (EPR) effect, allowing local release and diffusion of the active drug into target cells. Many marketed liposomal or lipidic drugs, of which DOXIL (Gabizon and Martin 1997; Barenholz 2012) is a notable example, fall into this category. Similarly, other nanomedicines, such as the antibody-radioisotope conjugates ZEVALIN (Witzig et al. 2002) and BEXXAR (Kaminski et al. 2001) are target receptors that are not internalized and therefore rely on irradiation from outside the cell for their activity. A broader discussion of nanomedicines, including these examples and others, has been thoroughly reviewed elsewhere (Allen and Cullis 2004; Farokhzad and Langer 2006; Peer et al. 2007; Davis et al. 2008; Sahay et al. 2010; Duncan and Gaspar 2011; Duncan and Richardson 2012). Although there are many ways to categorize and review the nanomedicines of today that use endocytosis, we have chosen to present these examples in three main categories: (1) those using phagocytosis for cellular specificity and delivery, (2) those using receptor-mediated endocytosis for cellular specificity and delivery, and (3) those requiring mechanisms for endocytic uptake and trafficking to specific (e.g., nonlysosomal) subcellular compartments (Table 1). Finally, we must concede that the list of nanomedicines reviewed here is not comprehensive but, rather, serves as exemplars of the types of nanomedicines in use today that exploit endocytosis to make a difference in the lives of patients.

Using a phagocytic route of cellular entry is one way of achieving cellular specificity by biasing, if not restricting, delivery to the cells of the reticuloendothelial system (RES) and other professionally phagocytic cells. As discussed above, particle size, shape, and surface chemistry can all impact the route of entry into cells and may be used to favor phagocytosis. A class of nanomedicines that exemplify this approach is the iron oxide particles, used primarily in two applications: (1) as intravenous (IV) iron supplements, and (2) as MRI contrast enhancement imaging agents. These particles consist of an iron oxide core stabilized by a carbohydrate coating. Iron is a critical component of heme and, therefore, of red blood cell production. The body has a sophisticated mechanism for absorbing, storing, and mobilizing iron for heme production, which can, under certain pathological conditions (e.g., blood loss, chronic kidney disease, chronic inflammatory disease), become dysregulated, leading to functional iron deficiency and resulting in iron deficiency anemia (Hentze et al. 2004, 2010; Nemeth et al. 2004). The goal of IV iron supplementation is to make the in vivo stores of iron replete, which happen to primarily reside in the macrophages of the liver and spleen. Therefore, the use of phagocytosis as an endocytic pathway is ideally suited for achieving cellular specificity in the delivery iron. The use of IV iron dextran to treat iron deficiency anemia goes back to the 1950s, and the use of other parenteral iron preparations goes back even further to the 1930s (Marchasin and Wallerstein 1964). There are several products that are on the market today for this indication, varying mainly by the carbohydrate coating used to stabilize the iron oxide core (Silverstein and Rodgers 2004). These products include Feraheme (polyglucose sorbitol car- 
Table 1. Selected examples of nanomedicines that exploit endocytosis

\begin{tabular}{|c|c|c|c|c|}
\hline Product & Description & Indication & Status & Source \\
\hline \multicolumn{5}{|c|}{ Phagocytosis for cellular specificity } \\
\hline Feraheme & $\begin{array}{l}\text { Iron oxide with polyglucose } \\
\text { sorbitol carboxymethyl } \\
\text { ether coating }\end{array}$ & IV iron supplement & Market & $\begin{array}{l}\text { AMAG Pharmaceuticals; } \\
\text { www.feraheme.com }\end{array}$ \\
\hline Venofer & $\begin{array}{l}\text { Iron oxide with sucrose } \\
\text { coating }\end{array}$ & IV iron supplement & & \\
\hline Ferrlecit & $\begin{array}{l}\text { Iron oxide with gluconate } \\
\text { coating }\end{array}$ & IV iron supplement & Market & Sanofi; www.ferreclit.com \\
\hline INFeD & $\begin{array}{l}\text { Iron oxide with low-MW } \\
\text { dextran coating }\end{array}$ & IV iron supplement & Market & Watson; www.infed.com \\
\hline Feridex & $\begin{array}{l}\text { Ferumoxides; } \\
\text { superparamagnetic iron } \\
\text { oxide nanoparticles } \\
\text { (SPIOs) }\end{array}$ & MRI contrast agent & Market & $\begin{array}{l}\text { AMAG Pharmaceuticals; no } \\
\text { longer manufactured }\end{array}$ \\
\hline Resovist & Ferucarbotran; SPIO & MRI contrast agent & Market & $\begin{array}{l}\text { Schering AG; no longer } \\
\text { manufactured }\end{array}$ \\
\hline Combidex & $\begin{array}{l}\text { Ferumoxtran; ultrasmall } \\
\text { superparamagnetic iron } \\
\text { oxides (USPIOs) }\end{array}$ & MRI contrast agent & Market & $\begin{array}{l}\text { AMAG Pharmaceuticals; no } \\
\text { longer manufactured }\end{array}$ \\
\hline \multicolumn{5}{|c|}{ Receptor-mediated endocytosis for cellular specificity } \\
\hline Ontak & $\begin{array}{l}\text { IL-2-diphtheria toxin fusion } \\
\text { protein }\end{array}$ & Cancer (CTCL) & Market & Esai; www.ontak.com \\
\hline Mylotarg & $\begin{array}{l}\text { Anti-CD33 antibody- } \\
\text { calicheamicin derivative; } \\
\text { hydrazone linker }\end{array}$ & Cancer (AML) & $\begin{array}{l}\text { Market; } \\
\text { withdrawn } \\
2010\end{array}$ & Wyeth/Pfizer \\
\hline Adcetris & $\begin{array}{l}\text { Anti-CD30 antibody- } \\
\text { MMAE; peptide linker }\end{array}$ & $\begin{array}{l}\text { Cancer (ALCL, } \\
\text { Hodgkin } \\
\text { lymphoma) }\end{array}$ & Market & $\begin{array}{l}\text { Seattle Genetics; } \\
\text { www.adcetris.com }\end{array}$ \\
\hline Kadcyla & $\begin{array}{l}\text { Anti-HER2 antibody- } \\
\text { mertansine derivative; } \\
\text { peptide linkage }\end{array}$ & Cancer (breast) & Market & $\begin{array}{l}\text { Roche/Genentech; } \\
\text { www.kadcyla.com }\end{array}$ \\
\hline Vintafolide & $\begin{array}{l}\text { Folate-vinblastine } \\
\quad \text { derivative; disulfide linker }\end{array}$ & $\begin{array}{l}\text { Cancer (ovarian, } \\
\text { NSCLC) }\end{array}$ & Phase III & $\begin{array}{l}\text { Endocyte/Merck; } \\
\text { www.endocyte.com }\end{array}$ \\
\hline Abraxane & $\begin{array}{l}\text { Nanoparticle albumin- } \\
\text { bound paclitaxel }\end{array}$ & Cancer (breast) & Market & $\begin{array}{l}\text { Cellgene; } \\
\text { www.abraxane.com }\end{array}$ \\
\hline BIND-014 & $\begin{array}{l}\text { PLGA-PEG nanoparticle- } \\
\text { encapsulating docetaxel; } \\
\text { anti-PSMA peptide } \\
\text { ligand }\end{array}$ & Cancer (prostate) & Phase I & BIND; www.bindbio.com \\
\hline \multicolumn{5}{|c|}{ Endocytic uptake and trafficking for subcellular delivery } \\
\hline Gendicine & Ad5-p53 gene therapy & Cancer (HNSCC) & Market & Shenzhen SiBiono GeneTech \\
\hline Oncorine & $\begin{array}{l}\text { Engineered p53-conditional } \\
\text { oncolytic Ad5 virus }\end{array}$ & Cancer (HNSCC) & Market & Shanghai Sunway Biotech \\
\hline Glybera & AAV1-LPL gene therapy & LPL deficiency & Market & $\begin{array}{l}\text { UniQure; } \\
\text { www.uniqure.com }\end{array}$ \\
\hline Kynamro & Anti-ApoB ASO & Homozygous FH & Market & $\begin{array}{l}\text { Genzyme/Isis; } \\
\text { www.kynamro.com }\end{array}$ \\
\hline CALAA-01 & $\begin{array}{l}\text { Cyclodextrin polymer- } \\
\text { based nanoparticle } \\
\text { encapsulating anti-RRM2 } \\
\text { siRNA }\end{array}$ & $\begin{array}{l}\text { Cancer (solid } \\
\text { tumor) }\end{array}$ & Phase I & $\begin{array}{l}\text { Arrowhead Research; } \\
\text { www.arrowheadresearch.com }\end{array}$ \\
\hline
\end{tabular}


A. Akinc and G. Battaglia

\begin{tabular}{|c|c|c|c|c|}
\hline Product & Description & Indication & Status & Source \\
\hline $\begin{array}{l}\text { ALN- } \\
\text { TTR02 }\end{array}$ & $\begin{array}{l}\text { LNP-encapsulating anti- } \\
\text { TTR siRNA }\end{array}$ & TTR amyloidosis & Phase II & $\begin{array}{l}\text { Alnylam; } \\
\text { www.alnylam.com }\end{array}$ \\
\hline ALN-VSP & $\begin{array}{l}\text { LNP-encapsulating anti- } \\
\text { VEGF and anti-KSP } \\
\text { siRNAs }\end{array}$ & $\begin{array}{l}\text { Cancer (solid } \\
\text { tumor) }\end{array}$ & Phase I & $\begin{array}{l}\text { Alnylam; } \\
\text { www.alnylam.com }\end{array}$ \\
\hline ALN-PCS & $\begin{array}{l}\text { LNP-encapsulating anti- } \\
\text { PCSK9 siRNA }\end{array}$ & $\begin{array}{l}\text { Hyperchole } \\
\text { sterolemia }\end{array}$ & Phase I & $\begin{array}{l}\text { Alnylam; } \\
\text { www.alnylam.com }\end{array}$ \\
\hline $\begin{array}{l}\text { TKM- } \\
\text { PLK1 }\end{array}$ & $\begin{array}{l}\text { LNP-encapsulating anti- } \\
\text { PLK1 siRNA }\end{array}$ & $\begin{array}{l}\text { Cancer (solid } \\
\text { tumor) }\end{array}$ & Phase I & $\begin{array}{l}\text { Tekmira; } \\
\text { www.tekmirapharm.com }\end{array}$ \\
\hline $\begin{array}{l}\text { TKM- } \\
\text { Ebola }\end{array}$ & $\begin{array}{l}\text { LNP-encapsulating anti- } \\
\text { Ebola siRNA }\end{array}$ & Ebola infection & Phase I & $\begin{array}{l}\text { Tekmira; } \\
\text { www.tekmirapharm.com }\end{array}$ \\
\hline $\begin{array}{l}\text { ALN- } \\
\text { TTRsc }\end{array}$ & $\begin{array}{l}\text { GalNAc-conjugated anti- } \\
\text { TTR siRNA }\end{array}$ & TTR amyloidosis & Phase I & Alnylam; www.alnylam.com \\
\hline
\end{tabular}

boxymethyl ether coating) (Spinowitz et al. 2008), Venofer (sucrose coating) (Yee and Besarab 2002), Ferrlecit (gluconate coating) (Nissenson et al. 1999), and INFeD (low-MW dextran coating) (Fletes et al. 2001). Upon IV injection, these products are rapidly internalized by cells of the RES, where they are then unpackaged to release elemental iron. The elemental iron $\left(\mathrm{Fe}^{3+}\right)$ is stored in ferritin, the ubiquitous intracellular iron storage protein that maintains iron in a soluble and nontoxic form. The carbohydrate coating is metabolized or excreted.

The phagocytic uptake properties of iron oxide particles have also been used in applications of MRI, where they dramatically shorten T2* relation time, serving as a contrast agent (Mendonca Dias and Lauterbur 1986; Saini et al. 1987a,b; Weissleder et al. 1987; Ferrucci and Stark 1990; Na et al. 2009). In this context, these particles are often characterized as superparamagnetic iron oxides (SPIOs) or ultrasmall $(<50 \mathrm{~nm})$ superparamagnetic iron oxides (USPIOs). Examples of such agents include Feridex (ferumoxides; SPIO), Resovist (ferucarbotran; SPIO), and Combidex (ferumoxtran; USPIO). Imaging contrast is achieved by differential distribution of the SPIOs and USPIOs inside the tissue, and this, in turn, is achieved by the differential distribution of cells with phagocytic capability within the tissue to be imaged. The typical application of SPIOs has been for the detection of lesions within the liver, because
SPIOs are taken up readily by the phagocytic Kupffer cells of the liver. If normal liver architecture is disrupted, for example, by primary liver tumor or secondary metastasis, this region will be devoid of Kupffer cells and, consequently, SPIOs. Therefore, with SPIO contrast enhancement, lesions can be detected via MRI as regions of negative contrast (see Figure 9A,B in Ferrucci and Stark 1990). This approach has been extended to lesion detection in lymph nodes through the use of USPIOs (Harisinghani et al. 2003). The smaller size of USPIOs allows for expanded distribution to lymph nodes, where again, lesions can be detected by negative contrast because of the absence of phagocytic macrophages in regions of disrupted architecture.

The use of receptor-mediated endocytosis is ideally suited for achieving targeted drug delivery, thereby improving both the efficacy and side-effect profile of nanomedicines. Although conceptually straightforward, the successful use of receptor-mediated endocytosis to achieve drug specificity in vivo is in practice more challenging. First, it is not always trivial to find suitable receptor-ligand pairs that are internalized, have the required level of target tissue specificity, and have high uptake capacity. Second, unlike controlled in vitro settings, specific uptake mechanisms rarely operate in isolation in vivo. Typically, specific delivery processes must compete with nonspecific delivery processes such as opsonization, RES clearance, and for particle 
Exploiting Endocytosis for Nanomedicines

systems, the EPR effect (Torchilin 2011). Nonetheless, receptor-mediated endocytosis remains an attractive means for achieving targeted delivery, and several nanomedicines using this strategy are in clinical development or have already made it to market.

One approach that has been successfully used clinically has been to generate prodrugs with targeting moieties covalently conjugated to drugs through a cleavable linkage (Fig. 4). This is particularly advantageous with cytotoxic drugs in the context of cancer therapy because efficacy can be increased and side effects minimized both by specific targeting to tumor cells and the use of a prodrug approach whereby the drug becomes active only once it is liberated inside the target cell (typically in the lysosome). Examples of such nanomedicines include Ontak (Olsen et al. 2001), Mylotarg (Nabhan and Tallman 2002), Adcetris (Younes et al. 2010), Kadcyla (Verma et al. 2012), and Vintafolide (Lorusso et al. 2012). Ontak (denileukin diftitox) is an interleukin-2 (IL-2)-diphtheria toxin fusion protein and was approved in 1999 for the treatment of cutaneous T-cell lymphoma (CTCL). It is targeted to the CD25 subunit of the IL-2 receptor on the surface of CTCL cells. Once internalized, the fusion protein is cleaved, releasing diphtheria toxin and resulting in cell death. Mylotarg (gemtuzumab ozogamicin) received accelerated approval for the treatment of $\mathrm{CD}_{3} 3^{+}$acute myeloid lymphoma (AML) in 2000. It was marketed from 2000 until 2010, when it was withdrawn from the market because of negative postapproval clinical trial re-

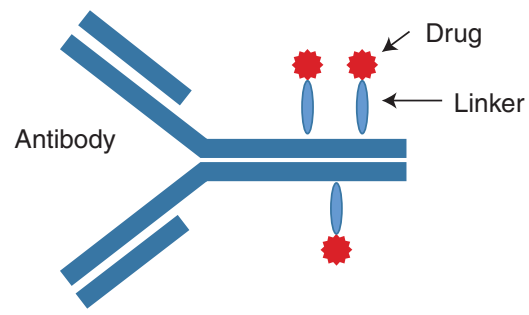

Antibody drug conjugate (ADC)

(e.g., Mylotarg, Adcetris, Kadcyla) sults. Mylotarg is an anti-CD33 antibody coupled to a calicheamicin derivative through an acid-cleavable hydrazone linker. Approximately $90 \%$ of $\mathrm{AML}$ cases are $\mathrm{CD}_{3}{ }^{+}$, and the antibody-CD33 complex is readily internalized and trafficked to lysosomes. The $\mathrm{pH}$-sensitive hydrazone linkage is hydrolyzed in the acid environment of the lysosome, releasing the calicheamicin drug. The calicheamicin derivative induces double-strand DNA breaks, leading to apoptosis. One liability of this first approved antibody-drug conjugate may have been the relative instability of the hydrazone linkage, resulting in premature hydrolysis while in circulation (Ducry and Stump 2010). Subsequentgeneration antibody-drug conjugates, such as Adcetris, have used more stable linker chemistry. Adcetris (brentuximab vedotin) was approved in 2011 for the treatment of anaplastic large cell lymphoma (ALCL) and Hodgkin's lymphoma. It is an anti-CD30 antibody linked to the antimitotic agent monomethyl auristatin $\mathrm{E}$ (MMAE) through a peptide linkage. In contrast to Mylotarg, which uses $\mathrm{pH}$ sensitivity for cleavage, Adcetris is cleaved enzymatically in the lysosome by lysosomal cysteine proteases such as cathepsin B (Ducry and Stump 2010). This strategy results in greater serum stability of the prodrug, limiting premature release of the drug. Kadcyla (ado-trastuzumab emtansine) was approved in 2013 for the treatment of advanced HER2-positive breast cancer. Kadcyla consists of trastuzumab (Herceptin) antibody-targeting HER2 linked to the cytotoxic agent mertansine. Vintafolide (EC145) is currently being studied

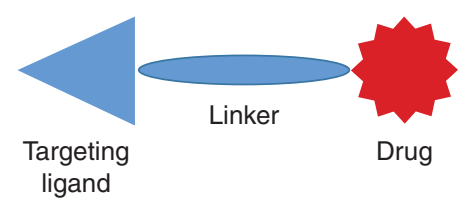

Targeted prodrug (e.g., Ontak, Vintafolide)

Figure 4. General structure of antibody drug conjugates (ADC) and targeted prodrugs. 
in the treatment of ovarian cancer and nonsmall-cell lung cancer (NSCLC). Vintafolide consists of a folate ligand conjugated to a vinblastine derivate through a disulfide linkage. The drug conjugate targets the folate receptor, which is overexpressed on many tumor types. Vintafolide is notable in that it uses a small-molecule-targeting ligand and is therefore significantly smaller than an antibody-drug conjugate. This property may allow for better tumor penetration. A companion diagnostic imaging agent is also available, Etarfolatide (EC20), which consists of the folate-targeting ligand conjugated to $99 \mathrm{~m}-\mathrm{Tc}$ (Reddy et al. 2004). This agent allows for both identification of tumors and for confirmation of the folate-receptor-positive status of a patient's tumor before treatment.

In addition to targeted drug conjugates, targeted nanoparticle systems have also been used to make use of receptor-mediated endocytosis to deliver a drug payload to target cells in vivo. The drug Abraxane uses nanoparticle albuminbound (nab) technology to encapsulate the hydrophobic drug paclitaxel in a Cremophor-free formulation (Gradishar et al. 2005, 2006; Miele et al. 2009). Abraxane was approved in 2005 for the treatment of breast cancer and consists of nanometer-sized (130 nm) particles of paclitaxel stabilized by human albumin. Abraxane is believed to use two distinct albumin-associated receptor-mediated endocytotic pathways for its in vivo activity. Upon intravenous administration, the particles disassociate into individual drug-bound albumin particles. These particles are then believed to interact with the gp60 receptor on endothelial cells, resulting in internalization and caveolae-based transcytosis across the endothelium to the subendothelial space. Once in the tumor interstitium, the drug-bound albumin particles are thought to interact with SPARC (secreted protein, acidic, and rich in cysteine). SPARC has been shown to be overexpressed by multiple tumor types, and the association of paclitaxel-bound albumin particles with SPARC is believed to result in enhanced uptake by tumor cells. Another example of a nanoparticle approach using receptor-mediated endocytosis for cellular targeting is the drug
BIND-014, which is currently in phase I trials for prostate cancer (Shi et al. 2011; Sanna and Sechi 2012). BIND-014 is notable because it not only uses ligand-based targeting, but also combines controlled release functionality to modulate drug pharmacokinetics. BIND-014 is a nanoparticle formulation of docetaxel, encapsulated in a controlled release poly(lactide-coglycolide)-poly(ethylene glycol) (PLGA-PEG) polymer. The system uses a peptide-based ligand targeting the extracellular domain of prostatespecific membrane antigen (PSMA), overexpressed in certain prostate cancers. BIND-014 is internalized via clathrin-mediated endocytosis, resulting in targeted delivery of the docetaxel drug payload.

Although the therapeutic profile of many drugs can be improved by exploiting endocytosis, for example, by either phagocytosis or receptor-mediated endocytosis to improve cellular targeting, there are other classes of therapeutics that are fully reliant on endocytic pathways for activity. Many of these drugs can be categorized as those requiring mechanisms for endocytic uptake and trafficking to specific, nonlysosomal subcellular compartments. Often these target compartments are the cytoplasm or nucleus. Nucleic-acid-based drugs-for example, plasmid DNA, antisense oligonucleotides, and RNA interference (RNAi) therapeutics - fall into this category and collectively represent an exciting emerging class of therapeutics.

After the cycle of early enthusiasm, and subsequent disappointment, experienced in the 1990s, the determined efforts of gene therapy researchers appear to now be bearing fruit. The key hurdle has been the safe and efficacious delivery of coding DNA, and both viral and nonviral delivery strategies have been pursued. Today, viral delivery approaches are the most prevalent and clinically advanced. Although often omitted in discussions of nanomedicines, viral gene therapy vectors should appropriately be included as nanomedicines exploiting endocytosis for therapeutic activity. Viral vectors typically show tissue tropism in vivo that is often driven by interactions of viral surface proteins with cellular receptors, leading to receptor-mediated endocytosis of the vector. Once 
Exploiting Endocytosis for Nanomedicines

internalized, viral vectors typically make use of viral and/or cellular factors to escape early or late endosomes, and thereby avoid trafficking to lysosomes. The first two gene therapy approvals, Gendicine (Peng 2005) in 2003 and Oncorine (Garber 2006) in 2006, have come in China. However, in late 2012, Glybera was approved in Europe, becoming the first gene therapy product approved outside of China (Yla-Herttuala 2012). Gendicine is a recombinant, replication-incompetent human adenovirus serotype 5 vector packaging the human wild-type p53 tumor suppressor gene (Ad5-p53), approved for the treatment of head and neck squamous cell carcinoma (HNSCC). Gendicine is injected intratumorally and induces the expression of the tumor suppressor p53, leading to apoptosis of tumor cells. Like Gendicine, Oncorine uses a recombinant human adenovirus serotype 5 and is indicated for the treatment of HNSCC. However, Oncorine is a conditionally oncolytic virus and, therefore, uses a different mechanism of action to kill tumor cells. It has been engineered to be replication incompetent in the presence of functional p53 (normal cells). In cells lacking p53 (tumor cells), the virus is able to replicate, ultimately lysing and killing the cells. Glybera (alipogene tiparvovec) is approved for the treatment of lipoprotein lipase deficiency (LPLD), a rare disease resulting in hypertriglyceridemia due to the absence of functional LPL enzyme. Glybera encodes the missing wild-type LPL gene packaged in an adeno-associated virus serotype 1 (AAV1) vector. AAV 1 is a suitable vector for this application because it displays natural tropism for muscle, the major site of LPL expression. Glybera is administered as a series of intramuscular injections.

Antisense oligonucleotides (ASOs) are chemically modified, short, single-stranded oligonucleotides that modulate protein expression through an RNase $\mathrm{H}$ mechanism (Bennett and Swayze 2010; Koller et al. 2011). Upon Watson-Crick base pairing to the target mRNA sequence, $\mathrm{RNase} \mathrm{H}$ is recruited to the RNA-DNA hybrid duplex region, resulting in enzymatic cleavage of the mRNA. Because this process occurs in the cytosol and/or nucleus, ASOs must reach these subcellular compartments for functional delivery. Over the past two decades, considerable effort has been made to optimize and develop ASOs as a novel nanomedicine class, with numerous candidates now in clinical trials. This effort has culminated in the recent January 2013 FDA approval of Kynamro (mipomersen sodium), an ASO-targeting apolipoprotein B, for the treatment of homozygous familial hypercholesterolemia. The precise mechanism by which ASOs are delivered to the appropriate intracellular compartments is poorly understood and an area of ongoing research. However, it has been reported that ASOs are taken up by liver cells via an as-yet-unknown nonclathrin-, noncaveolin-based endocytosis process (Koller et al. 2011). Furthermore, the same group reported the presence of both nonproductive delivery pathways, leading to delivery to lysosomes, as well as productive delivery pathways ( $<20 \%$ of delivered material) leading to delivery to the cytosol and nucleus.

RNAi therapeutics represent a new class of therapeutics that are typically synthetic short interfering RNAs (siRNAs) that engage the enzymatic RNA-induced silencing complex (RISC) in the cytosol of cells to down-regulate target mRNAs (Novina and Sharp 2004; Vaishnaw et al. 2010). By introducing a synthetic siRNA, these nanomedicines harness an endogenous conserved mechanism for gene regulation discovered in the late 1990s and for which a Nobel Prize was awarded in 2006. Although RNAi is a relatively new biological discovery, the advancement of therapeutics based on RNAi has been quite rapid, with numerous drug candidates in clinical trials. The rapid advancement of RNAi therapeutics is in no small part due to the groundwork laid by the gene therapy and antisense fields. Specifically, many of the approaches developed for nonviral gene delivery have been applied to the delivery of siRNAs, and many of the chemical modifications (to improve both stability and delivery properties) developed for ASOs have been successfully used for siRNAs. Like ASOs, it appears that siRNAs can also enter cells and traffic to the cytosol via as-yet-unknown, low-efficiency processes. Many of the early drug candidates were 
based on direct administration of siRNAs in local environments (e.g., ALN-RSV01 [Alvarez et al. 2009] and bevasiranib [Singerman 2009]). However, more recent RNAi therapeutic programs have used delivery systems that enable systemic administration and that include functionality to facilitate cytosolic delivery. The drug CALAA-01 is a cyclodextrin amino-polymerbased nanoparticle system that encapsulates an siRNA-targeting ribonucleotide reductase M2 (RRM2) and has completed a phase I trial for the treatment of solid tumors (Davis 2009). The system also incorporates a transferrin ligand to facilitate receptor-mediated endocytosis of the nanoparticle by target tumor cells overexpressing the transferrin receptor. The cyclodextrinbased polymer is thought to help destabilize the endosomes, enhancing endosomal release. Although a polymer-based delivery system has made it to clinical testing, lipid-nanoparticle (LNP)-based delivery systems are currently the most clinically validated, with numerous programs using LNPs in clinical trials. The most advanced among these is ALN-TTR02 (Coelho et al. 2013), which is currently in phase II trials for the treatment of transthyretin (TTR) amyloidosis, a rare disease resulting in peripheral neuropathy or cardiac myopathy due to toxic amyloid deposits formed from mutated TTR protein. Other clinical LNP-based programs include ALN-PCS, targeting PCSK9 for the treatment of hypercholesterolemia; ALN-VSP, targeting both VEGF and kinesin spindle protein (KSP) for the treatment of cancer (Tabernero et al. 2013); TKM-PLK1, targeting polo-like kinase 1 (PLK1) for the treatment of cancer; and TKM-Ebola, targeting the Ebola virus. These programs have either completed or are currently in phase I testing. These LNPs all contain ionizable lipids that are positively charged under acidic conditions and are uncharged under neutral physiological conditions (Zimmermann et al. 2006; Semple et al. 2010). These LNPs very effectively deliver siRNA to hepatocytes in vivo. It has been shown that this occurs via a specific process that is apolipoprotein E (apo E) mediated, mimicking the clearance process for chylomicron remnants (Akinc et al. 2010). LNPs pick up endogenous apo E in circulation, targeting the LNPs to hepatocytes via interaction of apo E with receptors such as LDLR, LRP1 , and SR-B1. After internalization by receptormediated endocytosis, the ionizable lipids of the LNP become positively charged as a result of the decreased $\mathrm{pH}$ of the endosome. The positively charged ionizable lipid is thought to become fusogenic, interacting with the endosomal membrane and releasing the siRNA into the cytosol. Following behind the LNPs are conjugatebased strategies for siRNA delivery. ALN-TTRsc recently initiated phase I testing and consists of an $N$-acetyl galactosamine (GalNAc)-conjugated siRNA targeting TTR. This conjugate takes advantage of the GalNAc-asialoglycoprotein receptor (ASGPR) interaction to deliver siRNA to hepatocytes via receptor-mediated endocytosis.

Endocytosis is the natural process by which cells sample their environment, transmitting signals and internalizing nutrients for maintenance and growth. The nanomedicines of today are being specifically designed to exploit this process, allowing for better cellular and subcellular targeting of drugs, leading to therapies with better efficacy and improved tolerability.

\section{UNANSWERED QUESTIONS AND REMAINING CHALLENGES}

Considerable progress has been made toward the elucidation of endocytosis pathways and the interaction of nanomedicines with these pathways, both by researchers working in fundamental biology, as well as applied nanotechnology fields. Studies by Gilleron et al. (2013) and Sahay et al. (2013) are recent examples of such progress, which elucidate the productive uptake pathways, intracellular trafficking/sorting events, and endosomal escape efficiencies of LNP-sRNA systems. Continued progress will require a sustained investment in research, both by industry and academia, and perhaps, most successfully, through partnerships between the two. As our understanding of how nanoparticle parameters impact endocytosis continues to deepen, this understanding is being exploited for the design of novel nanomedicines, many of which are already on the market or in clinical development. 
Nonetheless, significant unanswered questions and challenges remain, both for biologists and nanotechnologists, often working collaboratively, to address:

1. Tools for studying endocytosis. There is a continued need to develop new tools for the study of endocytic pathways. In particular, tools are needed to allow for the study of endocytosis directly (minimizing the introduction of artifacts), for effectively discriminating between different endocytic pathways, and for allowing more quantitative measurement of processes.

2. Tools for characterization of nanomedicines. Nanomedicines are often complex materials with properties that impact endocytic pathways and, ultimately, their pharmacology. Although bulk or average properties are typically characterized, it is often more challenging to characterize the distribution of these properties. However, it may be important to characterize, and ultimately control, the distribution of key properties (e.g., size, surface charge, shape, drug loading) to use nanomedicines effectively and safely.

3. Mixed mechanisms of endocytosis and determination of productive/nonproductive pathways. Rarely is a single endocytic pathway operative in isolation, and it is important to understand the relative contributions of different endocytic pathways to nanomedicine activity. It is a very significant challenge to study these pathways (often done through the use of chemical inhibitors) specifically without perturbing the system. Relatedly, nanomedicines are processed via both productive and nonproductive endocytic pathways, and it can be a major technical challenge to identify and study the productive pathways when they are dominated by nonproductive pathways.

4. Mechanisms of endosomal escape and sorting. Endosomal escape is a critical step for many classes of nanomedicines, including plasmid-, mRNA-, ASO-, and siRNA-based therapeutics. Although significant work has been performed to facilitate endosomal es-
Exploiting Endocytosis for Nanomedicines

cape, controversy remains regarding various endosomal escape mechanisms. More work is needed to elucidate these processes and to identify novel strategies for endosomal escape that are both efficacious and safe.

5. Cellular targeting. One of the attractive features of exploiting endocytosis for nanomedicine delivery is the opportunity for specific cellular targeting via receptor-mediated endocytosis. Although this approach is conceptually straightforward and has been successfully used by marketed nanomedicines, it is often challenging practically. New ligands for specific cell types remain to be discovered, new linker chemistries remain to be developed, and new strategies for avoiding nonspecific delivery mechanisms (in order to allow specific delivery) remain to be identified and implemented.

6. In vivo remodeling/opsonization of nanomedicines and impact on endocytosis. An important consideration for many nanomedicines is that they may undergo extensive remodeling or opsonization in vivo. As a consequence, thorough understanding and characterization of the nanomedicine in the vial may be insufficient to understand the ultimate form of the material as it is seen by cells in vivo. Therefore, prediction and control of nanomedicine pharmacology and endocytic trafficking require a better understanding of how materials are modified in vivo.

7. Safety considerations. Endocytosis pathways are critical to the proper functioning of the cell. Strategies used in the design of nanomedicines that exploit endocytosis must therefore avoid dysregulation of these critical pathways, not only acutely, but also with long-term chronic exposure. Safety aspects of the interaction between nanomedicines and the endocytic machinery warrant further study. In addition, when using strategies to facilitate endocytic delivery (e.g., fusogenic peptides for endosomal escape), consideration must also be given to broader safety concerns, such as immunogenicity and cytotoxicity. 
A. Akinc and G. Battaglia

\section{REFERENCES}

Ahmed F, Discher DE. 2004. Self-porating polymersomes of PEG-PLA and PEG-PCL: Hydrolysis-triggered controlled release vesicles. J Control Release 96: 37-53.

Ahmed F, Pakunlu RI, Srinivas G, Brannan A, Bates F, Klein ML, Minko T, Discher DE. 2006. Shrinkage of a rapidly growing tumor by drug-loaded polymersomes: $\mathrm{pH}-$ triggered release through copolymer degradation. $\mathrm{Mol}$ Pharm 3: 340-350.

Akin D, Sturgis J, Ragheb K, Sherman D, Burkholder K, Robinson JP, Bhunia AK, Mohammed S, Bashir R. 2007. Bacteria-mediated delivery of nanoparticles and cargo into cells. Nat Nanotechnol 2: 441-449.

Akinc A, Langer R. 2002. Measuring the $\mathrm{pH}$ environment of DNA delivered using nonviral vectors: Implications for lysosomal trafficking. Biotechnol Bioeng 78: 503508.

Akinc A, Querbes W, De S, Qin J, Frank-Kamenetsky M, Jayaprakash KN, Jayaraman M, Rajeev KG, Cantley WL, Dorkin JR, et al. 2010. Targeted delivery of RNAi therapeutics with endogenous and exogenous ligand-based mechanisms. Mol Ther 18: 1357-1364.

Albanese A, Chan WC. 2011. Effect of gold nanoparticle aggregation on cell uptake and toxicity. ACS Nano 5: 5478-5489.

Alcantar NA, Aydil ES, Israelachvili JN. 2000. Polyethylene glycol-coated biocompatible surfaces. J Biomed Mater Res 51: 343-351.

Allen TM, Cullis PR. 2004. Drug delivery systems: Entering the mainstream. Science 303: 1818-1822.

Alvarez R, Elbashir S, Borland T, Toudjarska I, Hadwiger P, John M, Roehl I, Morskaya SS, Martinello R, Kahn J, et al. 2009. RNA interference-mediated silencing of the respiratory syncytial virus nucleocapsid defines a potent antiviral strategy. Antimicrob Agents Chemother 53: 39523962.

Anderson RG. 1998. The caveolae membrane system. Annu Rev Biochem 67: 199-225.

Asati A, Santra S, Kaittanis C, Perez JM. 2010. Surface-charge-dependent cell localization and cytotoxicity of cerium oxide nanoparticles. ACS Nano 4: 5321-5331.

Barenholz Y. 2012. Doxil-The first FDA-approved nanodrug: Lessons learned. J Control Release 160: 117-134.

Barrett DA, Hartshome MS, Hussain MA, Shaw PN, Davies MC. 2001. Resistance to nonspecific protein adsorption by poly(vinyl alcohol) thin films adsorbed to a poly(styrene) support matrix studied using surface plasmon resonance. Anal Chem 73: 5232-5239.

Barua S, Yoo JW, Kolhar P, Wakankar A, Gokarn YR, Mitragotri S. 2013. Particle shape enhances specificity of antibody-displaying nanoparticles. Proc Natl Acad Sci 110: 3270-3275.

Behr JP. 1997. The proton sponge: A trick to enter cells the viruses did not exploit. Chimia 51: 34-36.

Bennett CF, Swayze EE. 2010. RNA targeting therapeutics: Molecular mechanisms of antisense oligonucleotides as a therapeutic platform. Annu Rev Pharmacol Toxicol 50: 259-293.

Bieber T, Meissner W, Kostin S, Niemann A, Elsasser HP. 2002. Intracellular route and transcriptional competence of polyethylenimine-DNA complexes. J Control Release 82: $441-454$.

Blanazs A, Massignani M, Battaglia G, Armes SP, Ryan AJ. 2009. Tailoring macromolecular expression at polymersome surfaces. Adv Funct Mater 19: 2906-2914.

Boussif O, Lezoualc'h F, Zanta MA, Mergny MD, Scherman D, Demeneix B, Behr JP. 1995. A versatile vector for gene and oligonucleotide transfer into cells in culture and in vivo: Polyethylenimine. Proc Natl Acad Sci 92: 72977301.

Canton I, Battaglia G. 2012. Endocytosis at the nanoscale. Chem Soc Rev 41: 2718-2739.

Canton I, Massignani M, Patikarnmonthon N, Chierico L, Robertson J, Renshaw SA, Warren NJ, Madsen JP, Armes SP, Lewis AL, et al. 2013. Fully synthetic polymer vesicles for intracellular delivery of antibodies in live cells. FASEB J 27: 98-108.

Caracciolo G, Caminiti R, Digman MA, Gratton E, Sanchez S. 2009. Efficient escape from endosomes determines the superior efficiency of multicomponent lipoplexes. J Phys Chem B 113: 4995-4997.

Cerritelli S, Velluto D, Hubbell JA. 2007. PEG-SS-PPS: Reduction-sensitive disulfide block copolymer vesicles for intracellular drug delivery. Biomacromolecules 8: 19661972.

Champion JA, Mitragotri S. 2006. Role of target geometry in phagocytosis. Proc Natl Acad Sci 103: 4930-4934.

Chaudhuri A, Battaglia G, Golestanian R. 2011. The effect of interactions on the cellular uptake of nanoparticles. Phys Biol 8: 046002.

Chen SF, Li LY, Zhao C, Zheng J. 2010. Surface hydration: Principles and applications toward low-fouling/nonfouling biomaterials. Polymer 51: 5283-5293.

Chithrani BD, Chan WC. 2007. Elucidating the mechanism of cellular uptake and removal of protein-coated gold nanoparticles of different sizes and shapes. Nano Lett 7: $1542-1550$.

Chithrani BD, Ghazani AA, Chan WC. 2006. Determining the size and shape dependence of gold nanoparticle uptake into mammalian cells. Nano Lett 6: 662-668.

Chnari E, Nikitczuk JS, Wang J, Uhrich KE, Moghe PV. 2006. Engineered polymeric nanoparticles for receptor-targeted blockage of oxidized low density lipoprotein uptake and atherogenesis in macrophages. Biomacromolecules 7: 1796-1805.

Cho EC, Xie J, Wurm PA, Xia Y. 2009. Understanding the role of surface charges in cellular adsorption versus internalization by selectively removing gold nanoparticles on the cell surface with a I2/KI etchant. Nano Lett 9: 1080-1084.

Clement C, Tiwari V, Scanlan PM, Valyi-Nagy T, Yue BY, Shukla D. 2006. A novel role for phagocytosis-like uptake in herpes simplex virus entry. J Cell Biol 174: 1009-1021.

Coelho T, Adams D, Silva A, Lozeron P, Hawkins PN, Mant T, Perez J, Chiesa J, Warrington S, Tranter E, et al. 2013. Safety and efficacy of an RNAi therapeutic targeting transthyretin (TTR) for TTR amyloidosis. N Engl J Med 369: 819-829.

Corsi F, De Palma C, Colombo M, Allevi R, Nebuloni M, Ronchi S, Rizzi G, Tosoni A, Trabucchi E, Clementi E, et al. 2009. Towards ideal magnetofluorescent nanoparticles 
for bimodal detection of breast-cancer cells. Small 5: $2555-2564$.

Dagastine RR, Manica R, Carnie SL, Chan DY, Stevens GW, Grieser F. 2006. Dynamic forces between two deformable oil droplets in water. Science 313: 210-213.

Davis ME. 2009. The first targeted delivery of siRNA in humans via a self-assembling, cyclodextrin polymerbased nanoparticle: From concept to clinic. Mol Pharm 6: 659-668.

Davis ME, Chen ZG, Shin DM. 2008. Nanoparticle therapeutics: An emerging treatment modality for cancer. Nat Rev Drug Discov 7: 771-782.

Deserno M. 2004. Elastic deformation of a fluid membrane upon colloid binding. Phys Rev E 69: 031903.

Dimitrov DS. 2004. Virus entry: Molecular mechanisms and biomedical applications. Nat Rev Microbiol 2: 109-122.

Discher DE, Eisenberg A. 2002. Polymer vesicles. Science 297: 967-973.

Doherty GJ, McMahon HT. 2009. Mechanisms of endocytosis. Annu Rev Biochem 78: 857-902.

Du J, Tang Y, Lewis AL, Armes SP. 2005. pH-sensitive vesicles based on a biocompatible zwitterionic diblock copolymer. J Am Chem Soc 127: 17982-17983.

Ducry L, Stump B. 2010. Antibody-drug conjugates: Linking cytotoxic payloads to monoclonal antibodies. Bioconjug Chem 21: 5-13.

Duncan R, Gaspar R. 2011. Nanomedicine(s) under the microscope. Mol Pharm 8: 2101-2141.

Duncan R, Richardson SC. 2012. Endocytosis and intracellular trafficking as gateways for nanomedicine delivery: Opportunities and challenges. Mol Pharm 9: 2380-2402.

Ehrlich M, Boll W, Van Oijen A, Hariharan R, Chandran K, Nibert ML, Kirchhausen T. 2004. Endocytosis by random initiation and stabilization of clathrin-coated pits. Cell 118: 591-605.

Erbacher P, Roche AC, Monsigny M, Midoux P. 1996. Putative role of chloroquine in gene transfer into a human hepatoma cell line by DNA lactosylated polylysine complexes. Exp Cell Res 225: 186-194.

Farokhzad OC, Langer R. 2006. Nanomedicine: Developing smarter therapeutic and diagnostic modalities. Adv Drug Deliv Rev 58: 1456-1459.

Ferrucci JT, Stark DD. 1990. Iron oxide-enhanced MR imaging of the liver and spleen: Review of the first 5 years. AJR Am J Roentgenol 155: 943-950.

Fischer HC, Hauck TS, Gomez-Aristizabal A, Chan WC 2010. Exploring primary liver macrophages for studying quantum dot interactions with biological systems. $A d v$ Mater 22: 2520-2524.

Fletes R, Lazarus JM, Gage J, Chertow GM. 2001. Suspected iron dextran-related adverse drug events in hemodialysis patients. Am J Kidney Dis 37: 743-749.

Franca A, Aggarwal P, Barsov EV, Kozlov SV, Dobrovolskaia MA, Gonzalez-Fernandez A. 2011. Macrophage scavenger receptor A mediates the uptake of gold colloids by macrophages in vitro. Nanomedicine 6: 1175-1188.

Francois P, Vaudaux P, Nurdin N, Mathieu HJ, Descouts P, Lew DP. 1996. Physical and biological effects of a surface coating procedure on polyurethane catheters. Biomaterials 17: $667-678$.
Frost A, Unger VM, De Camilli P. 2009. The BAR domain superfamily: Membrane-molding macromolecules. Cell 137: 191-196.

Gabizon A, Martin F. 1997. Polyethylene glycol-coated (pegylated) liposomal doxorubicin. Rationale for use in solid tumours. Drugs 54: 15-21.

Gao H, Shi W, Freund LB. 2005. Mechanics of receptormediated endocytosis. Proc Natl Acad Sci 102: 94699474.

Garber K. 2006. China approves world's first oncolytic virus therapy for cancer treatment. J Natl Cancer Inst 98: 298 300 .

Ghigo E, Kartenbeck J, Lien P, Pelkmans L, Capo C, Mege JL, Raoult D. 2008. Ameobal pathogen mimivirus infects macrophages through phagocytosis. PLoS Pathogens 4: e1000087.

Gilleron J, Querbes W, Zeigerer A, Borodovsky A, Marsico G, Schubert U, Manygoats K, Seifert S, Andree C, Stöter $\mathrm{M}$, et al. 2013. Image-based analysis of lipid nanoparticle-mediated siRNA delivery, intracellular trafficking and endosomal escape. Nat Biotechnol 31: 638-646.

Godbey WT, Barry MA, Saggau P, Wu KK, Mikos AG. 2000. Poly(ethylenimine)-mediated transfection: A new paradigm for gene delivery. J Biomed Mater Res 51: 321-328.

Gradishar WJ. 2006. Albumin-bound paclitaxel: A nextgeneration taxane. Expert Opin Pharmacother 7: 10411053.

Gradishar WJ, Tjulandin S, Davidson N, Shaw H, Desai N, Bhar P, Hawkins M, O’Shaughnessy J. 2005. Phase III trial of nanoparticle albumin-bound paclitaxel compared with polyethylated castor oil-based paclitaxel in women with breast cancer. J Clin Oncol 23: 7794-7803.

Gratton SE, Ropp PA, Pohlhaus PD, Luft JC, Madden VJ, Napier ME, DeSimone JM. 2008. The effect of particle design on cellular internalization pathways. Proc Natl Acad Sci 105: 11613-11618.

Gruenberg J. 2001. The endocytic pathway: A mosaic of domains. Nat Rev Mol Cell Biol 2: 721-730.

Gruenberg J, van der Goot FG. 2006. Mechanisms of pathogen entry through the endosomal compartments. Nat Rev Mol Cell Biol 7: 495-504.

Grunewald K, Desai P, Winkler DC, Heymann JB, Belnap DM, Baumeister W, Steven AC. 2003. Three-dimensiona structure of herpes simplex virus from cryo-electron tomography. Science 302: 1396-1398.

Han X, Liu J, Liu M, Xie C, Zhan C, Gu B, Liu Y, Feng L, Lu W. 2009. 9-NC-loaded folate-conjugated polymer micelles as tumor targeted drug delivery system: Preparation and evaluation in vitro. Int J Pharm 372: 125-131.

Harisinghani MG, Barentsz J, Hahn PF, Deserno WM, Tabatabaei S, van de Kaa CH, de la Rosette J, Weissleder R. 2003. Noninvasive detection of clinically occult lymphnode metastases in prostate cancer. $N$ Engl J Med 348: 2491-2499.

Harris JM, Chess RB. 2003. Effect of pegylation on pharmaceuticals. Nat Rev Drug Discov 2: 214-221.

Harris A, Cardone G, Winkler DC, Heymann JB, Brecher M, White JM, Steven AC. 2006. Influenza virus pleiomorphy characterized by cryoelectron tomography. Proc Natl Acad Sci 103: 19123-19127. 
Hearnden V, Lomas H, Macneil S, Thornhill M, Murdoch C, Lewis A, Madsen J, Blanazs A, Armes S, Battaglia G. 2009. Diffusion studies of nanometer polymersomes across tissue engineered human oral mucosa. Pharm Res 26: $1718-1728$.

Hentze MW, Muckenthaler MU, Andrews NC. 2004. Balancing acts: Molecular control of mammalian iron metabolism. Cell 117: 285-297.

Hentze MW, Muckenthaler MU, Galy B, Camaschella C. 2010. Two to tango: Regulation of mammalian iron metabolism. Cell 142: 24-38.

Heuser JE, Reese TS. 1973. Evidence for recycling of synaptic vesicle membrane during transmitter release at the frog neuromuscular junction. J Cell Biol 57: 315-344.

Hu Y, Litwin T, Nagaraja AR, Kwong B, Katz J, Watson N, Irvine DJ. 2007. Cytosolic delivery of membrane-impermeable molecules in dendritic cells using $\mathrm{pH}$-responsive core-shell nanoparticles. Nano Lett 7: 3056-3064.

Huang J, Bu L, Xie J, Chen K, Cheng Z, Li X, Chen X. 2010. Effects of nanoparticle size on cellular uptake and liver MRI with polyvinylpyrrolidone-coated iron oxide nanoparticles. ACS Nano 4: 7151-7160.

Hunter AC, Moghimi SM. 2010. Cationic carriers of genetic material and cell death: A mitochondrial tale. Biochim Biophys Acta 1797: 1203-1209.

Hutter E, Boridy S, Labrecque S, Lalancette-Hebert M, Kriz J, Winnik FM, Maysinger D. 2010. Microglial response to gold nanoparticles. ACS Nano 4: 2595-2606.

Iinuma $\mathrm{H}$, Maruyama $\mathrm{K}$, Okinaga $\mathrm{K}$, Sasaki $\mathrm{K}$, Sekine T, Ishida O, Ogiwara N, Johkura K, Yonemura Y. 2002. Intracellular targeting therapy of cisplatin-encapsulated transferrin-polyethylene glycol liposome on peritoneal dissemination of gastric cancer. Int J Cancer 99: 130-137.

Ishihara K, Fukumoto K, Iwasaki Y, Nakabayashi N. 1999. Modification of polysulfone with phospholipid polymer for improvement of the blood compatibility. Part 1: Surface characterization. Biomaterials 20: 1545-1551.

Jiang W, Kim BY, Rutka JT, Chan WC. 2008. Nanoparticlemediated cellular response is size-dependent. Nat Nanotechnol 3: 145-150.

Jin H, Heller DA, Sharma R, Strano MS. 2009. Size-dependent cellular uptake and expulsion of single-walled carbon nanotubes: Single particle tracking and a generic uptake model for nanoparticles. ACS Nano 3: 149-158.

Joanne P, Nicolas P, El Amri C. 2009. Antimicrobial peptides and viral fusion peptides: How different they are? Protein Pept Lett 16: 743-750.

Jones AT, Sayers EJ. 2012. Cell entry of cell penetrating peptides: Tales of tails wagging dogs. J Controlled Release 161: $582-591$.

Jones RA, Cheung CY, Black FE, Zia JK, Stayton PS, Hoffman AS, Wilson MR. 2003. Poly(2-alkylacrylic acid) polymers deliver molecules to the cytosol by $\mathrm{pH}$-sensitive disruption of endosomal vesicles. Biochem J 372: 65-75.

Kaminski MS, Zelenetz AD, Press OW, Saleh M, Leonard J, Fehrenbacher L, Lister TA, Stagg RJ, Tidmarsh GF, Kroll S, et al. 2001. Pivotal study of iodine I 131 tositumomab for chemotherapy-refractory low-grade or transformed lowgrade B-cell non-Hodgkin's lymphomas. J Clin Oncol 19: 3918-3928.
Kim Y, Tewari M, Pajerowski JD, Cai S, Sen S, Williams JH, Sirsi SR, Lutz GJ, Discher DE. 2009. Polymersome delivery of siRNA and antisense oligonucleotides. J Controlled Release 134: 132-140.

Kirpotin DB, Drummond DC, Shao Y, Shalaby MR, Hong K, Nielsen UB, Marks JD, Benz CC, Park JW. 2006. Antibody targeting of long-circulating lipidic nanoparticles does not increase tumor localization but does increase internalization in animal models. Cancer Res 66: 67326740.

Kitano H, Suzuki H, Matsuura K, Ohno K. 2010. Molecular recognition at the exterior surface of a zwitterionic telomer brush. Langmuir 26: 6767-6774.

Koller E, Vincent TM, Chappell A, De S, Manoharan M, Bennett CF. 2011. Mechanisms of single-stranded phosphorothioate modified antisense oligonucleotide accumulation in hepatocytes. Nucleic Acids Res 39: $4795-$ 4807.

Koltover I, Salditt T, Radler JO, Safinya CR. 1998. An inverted hexagonal phase of cationic liposome-DNA complexes related to DNA release and delivery. Science 281: 78 81.

Konradi R, Pidhatika B, Muhlebach A, Textor M. 2008. Poly2-methyl-2-oxazoline: A peptide-like polymer for protein-repellent surfaces. Langmuir 24: 613-616.

Kratz F. 2008. Albumin as a drug carrier: Design of prodrugs, drug conjugates and nanoparticles. J Control Release 132: 171-183.

Krpetic Z, Porta F, Caneva E, Dal Santo V, Scari G. 2010. Phagocytosis of biocompatible gold nanoparticles. Langmuir 26: 14799-14805.

Kumari S, Mg S, Mayor S. 2010. Endocytosis unplugged: Multiple ways to enter the cell. Cell Res 20: 256-275.

Kurzchalia TV, Parton RG. 1999. Membrane microdomains and caveolae. Curr Opin Cell Biol 11: 424-431.

Kusonwiriyawong C, van de Wetering P, Hubbell JA, Merkle HP, Walter E. 2003. Evaluation of pH-dependent membrane-disruptive properties of poly(acrylic acid) derived polymers. Eur J Pharm Biopharm 56: 237-246.

Kwon EJ, Bergen JM, Park IK, Pun SH. 2008. Peptide-modified vectors for nucleic acid delivery to neurons. J Control Release 132: 230-235.

Kwon EJ, Liong S, Pun SH. 2010. A truncated HGP peptide sequence that retains endosomolytic activity and improves gene delivery efficiencies. Mol Pharma 7: 12601265.

Kyriakides TR, Cheung CY, Murthy N, Bornstein P, Stayton PS, Hoffman AS. 2002. pH-sensitive polymers that enhance intracellular drug delivery in vivo. J Control Release 78: $295-303$.

Leckband D, Israelachvili J. 2001. Intermolecular forces in biology. Q Rev Biophys 34: 105-267.

Lee RJ, Low PS. 1994. Delivery of liposomes into cultured $\mathrm{KB}$ cells via folate receptor-mediated endocytosis. J Biol Chem 269: 3198-3204.

Lee LK, Williams CL, Devore D, Roth CM. 2006. Poly(propylacrylic acid) enhances cationic lipid-mediated delivery of antisense oligonucleotides. Biomacromolecules 7: $1502-1508$.

Lee H, Hu M, Reilly RM, Allen C. 2007. Apoptotic epidermal growth factor (EGF)-conjugated block copolymer 
micelles as a nanotechnology platform for targeted combination therapy. Mol Pharma 4: 769-781.

Lemarchand C, Gref R, Couvreur P. 2004. Polysaccharidedecorated nanoparticles. Eur J Pharm Biopharm 58: 327341.

Lesniak A, Campbell A, Monopoli MP, Lynch I, Salvati A, Dawson KA. 2010. Serum heat inactivation affects protein corona composition and nanoparticle uptake. Biomaterials 31: 9511-9518.

Lewis AL. 2000. Phosphorylcholine-based polymers and their use in the prevention of biofouling. J Colloids Surf B 18: 261 .

Lin J, Zhang H, Chen Z, Zheng Y. 2010. Penetration of lipid membranes by gold nanoparticles: Insights into cellular uptake, cytotoxicity, and their relationship. ACS Nano 4: 5421-5429.

Lingwood D, Simons K. 2010. Lipid rafts as a membraneorganizing principle. Science 327: 46-50.

Linse S, Cabaleiro-Lago C, Xue WF, Lynch I, Lindman S, Thulin E, Radford SE, Dawson KA. 2007. Nucleation of protein fibrillation by nanoparticles. Proc Natl Acad Sci 104: 8691-8696.

Lipowsky R, Dobereiner HG. 1998. Vesicles in contact with nanoparticles and colloids. Europhys Lett 43: 219-225.

Lomas H, Canton I, MacNeil S, Du J, Armes SP, Ryan AJ, Lewis AL, Battaglia G. 2007. Biomimetic pH sensitive polymersomes for efficient DNA encapsulation and delivery. Adv Mater 19: 4238-4242.

Lomas H, Massignani M, Abdullah KA, Canton I, Lo Presti C, MacNeil S, Du J, Blanazs A, Madsen J, Armes SP, et al. 2008. Non-cytotoxic polymer vesicles for rapid and efficient intracellular delivery. Faraday Discuss 139: 143$159-$.

LoPresti C, Lomas H, Massignani M, Smart T, Battaglia G 2009. Polymersomes: Nature inspired nanometer sized compartments. J Mater Chem 19: 3576-3590.

LoPresti C, Massignani M, Fernyhough C, Blanazs A, Ryan AJ, Madsen J, Warren NJ, Armes SP, Lewis AL, Chirasatitsin S, et al. 2011. Controlling polymersome surface topology at the nanoscale by membrane confined polymer/polymer phase separation. ACS Nano 5: 1775-1784.

Lorusso PM, Edelman MJ, Bever SL, Forman KM, Pilat M, Quinn MF, Li J, Heath EI, Malburg LM, Klein PJ, et al. 2012. Phase I study of folate conjugate EC145 (Vintafolide) in patients with refractory solid tumors. J Clin Oncol 30: 4011-4016.

Lundqvist M, Stigler J, Cedervall T, Berggard T, Flanagan MB, Lynch I, Elia G, Dawson K. 2011. The evolution of the protein corona around nanoparticles: A test study. ACS Nano 5: 7503-7509.

Lunov O, Syrovets T, Loos C, Beil J, Delacher M, Tron K, Nienhaus GU, Musyanovych A, Mailander V, Landfester $\mathrm{K}$, et al. 2011. Differential uptake of functionalized polystyrene nanoparticles by human macrophages and a monocytic cell line. ACS Nano 5: 1657-1669.

Lynch I, Dawson KA, Linse S. 2006. Detecting cryptic epitopes created by nanoparticles. Sci STKE 2006: e14.

Maiorano G, Sabella S, Sorce B, Brunetti V, Malvindi MA Cingolani R, Pompa PP. 2010. Effects of cell culture media on the dynamic formation of protein-nanoparticle complexes and influence on the cellular response. ACS Nano 4: 7481-7491.

Marchasin S, Wallerstein RO. 1964. The treatment of irondeficiency anemia with intravenous iron dextran. Blood 23: $354-358$.

Marsh M, Helenius A. 2006. Virus entry: Open sesame. Cell 124: 729-740.

Massignani M, LoPresti C, Blanazs A, Madsen J, Armes SP, Lewis AL, Battaglia G. 2009. Controlling cellular uptake by surface chemistry, size, and surface topology at the nanoscale. Small 5: 2424-2432.

Massignani M, Canton I, Sun T, Hearnden V, Macneil S, Blanazs A, Armes SP, Lewis A, Battaglia G. 2010. Enhanced fluorescence imaging of live cells by effective cytosolic delivery of probes. PloS ONE 5: e10459.

Mastrobattista E, Koning GA, van Bloois L, Filipe ACS, Jiskoot W, Storm G. 2002. Functional characterization of an endosome-disruptive peptide and its application in cytosolic delivery of immunoliposome-entrapped proteins. J Biol Chem 277: 27135-27143.

Mayor S, Pagano RE. 2007. Pathways of clathrin-independent endocytosis. Nat Rev Mol Cell Biol 8: 603-612.

McMahon HT, Gallop JL. 2005. Membrane curvature and mechanisms of dynamic cell membrane remodelling. Nature 438: 590-596.

Mendonca Dias MH, Lauterbur PC. 1986. Ferromagnetic particles as contrast agents for magnetic resonance imaging of liver and spleen. Magn Reson Med 3: 328-330.

Meng F, Zhong Z, Feijen J. 2009. Stimuli-responsive polymersomes for programmed drug delivery. Biomacromolecules 10: 197-209.

Mercer J, Schelhaas M, Helenius A. 2010. Virus entry by endocytosis. Ann Rev Biochem 79: 803-833.

Mi Y, Zhao J, Feng SS. 2013. Targeted co-delivery of docetaxel, cisplatin and herceptin by vitamin E TPGS-cisplatin prodrug nanoparticles for multimodality treatment of cancer. J Control Release 169: 185-192.

Miele E, Spinelli GP, Tomao F, Tomao S. 2009. Albuminbound formulation of paclitaxel (Abraxane ABI-007) in the treatment of breast cancer. Int J Nanomedicine 4: 99105.

Miller CR, Bondurant B, McLean SD, McGovern KA, O'Brien DF. 1998. Liposome-cell interactions in vitro: Effect of liposome surface charge on the binding and endocytosis of conventional and sterically stabilized liposomes. Biochemistry 37: 12875-12883.

Mislick KA, Baldeschwieler JD. 1996. Evidence for the role of proteoglycans in cation-mediated gene transfer. Proc Natl Acad Sci 93: 12349-12354.

Moghimi SM, Patel HM. 2002. Modulation of murine liver macrophage clearance of liposomes by diethylstilbestrol. The effect of vesicle surface charge and a role for the complement receptor Mac-1 (CD11b/CD18) of newly recruited macrophages in liposome recognition. J Control Release 78: 55-65.

Moghimi SM, Symonds P, Murray JC, Hunter AC, Debska G, Szewczyk A. 2005. A two-stage poly(ethylenimine)mediated cytotoxicity: Implications for gene transfer/ therapy. Mol Therapy 11: 990-995.

Monopoli MP, Walczyk D, Campbell A, Elia G, Lynch I, Bombelli FB, Dawson KA. 2011. Physical-chemical as- 
A. Akinc and G. Battaglia

pects of protein corona: Relevance to in vitro and in vivo biological impacts of nanoparticles. J Am Chem Soc 133: 2525-2534.

$\mathrm{Na}$ HB, Song IC, Hyeon T. 2009. Inorganic nanoparticles for MRI contrast agents. Adv Mater 21: 2133-2148.

Nabhan C, Tallman MS. 2002. Early phase I/II trials with gemtuzumab ozogamicin (Mylotarg) in acute myeloid leukemia. Clin Lymphoma 2: S19-23.

Nakai T, Kanamori T, Sando S, Aoyama Y. 2003. Remarkably size-regulated cell invasion by artificial viruses. Saccharide-dependent self-aggregation of glycoviruses and its consequences in glycoviral gene delivery. $\mathrm{J} \mathrm{Am} \mathrm{Chem}$ Soc 125: 8465-8475.

Nam HY, Kwon SM, Chung H, Lee SY, Kwon SH, Jeon H, Kim Y, Park JH, Kim J, Her S, et al. 2009. Cellular uptake mechanism and intracellular fate of hydrophobically modified glycol chitosan nanoparticles. J Control Release 135: 259-267.

Nel AE, Madler L, Velegol D, Xia T, Hoek EM, Somasundaran P, Klaessig F, Castranova V, Thompson M. 2009. Understanding biophysicochemical interactions at the nano-bio interface. Nat Mater 8: 543-557.

Nemeth E, Tuttle MS, Powelson J, Vaughn MB, Donovan A, Ward DM, Ganz T, Kaplan J. 2004. Hepcidin regulates cellular iron efflux by binding to ferroportin and inducing its internalization. Science 306: 2090-2093.

Neu M, Fischer D, Kissel T. 2005. Recent advances in rational gene transfer vector design based on poly(ethylene imine) and its derivatives. J Gene Med 7: 992-1009.

Nissenson AR, Lindsay RM, Swan S, Seligman P, Strobos J. 1999. Sodium ferric gluconate complex in sucrose is safe and effective in hemodialysis patients: North American Clinical Trial. Am J Kidney Dis 33: 471-482.

Novina CD, Sharp PA. 2004. The RNAi revolution. Nature 430: $161-164$.

Olsen E, Duvic M, Frankel A, Kim Y, Martin A, Vonderheid E, Jegasothy B, Wood G, Gordon M, Heald P, et al. 2001. Pivotal phase III trial of two dose levels of denileukin diftitox for the treatment of cutaneous T-cell lymphoma. J Clin Oncol 19: 376-388.

Pan XQ, Zheng X, Shi G, Wang H, Ratnam M, Lee RJ. 2002. Strategy for the treatment of acute myelogenous leukemia based on folate receptor $\beta$-targeted liposomal doxorubicin combined with receptor induction using alltrans retinoic acid. Blood 100: 594-602.

Park J, Lim DH, Lim HJ, Kwon T, Choi JS, Jeong S, Choi IH, Cheon J. 2011. Size dependent macrophage responses and toxicological effects of $\mathrm{Ag}$ nanoparticles. Chem Commun 47: 4382-4384.

Patil ML, Zhang M, Taratula O, Garbuzenko OB, He H, Minko T. 2009. Internally cationic polyamidoamine PAMAM-OH dendrimers for siRNA delivery: Effect of the degree of quaternization and cancer targeting. Biomacromolecules 10: 258-266.

Peer D, Karp JM, Hong S, Farokhzad OC, Margalit R, Langer R. 2007. Nanocarriers as an emerging platform for cancer therapy. Nat Nanotechnol 2: 751-760.

Pelkmans L, Helenius A. 2002. Endocytosis via caveolae. Traffic 3: 311-320.
Peng Z. 2005. Current status of gendicine in China: Recombinant human Ad-p53 agent for treatment of cancers. Hum Gene Ther 16: 1016-1027.

Perry JL, Herlihy KP, Napier ME, Desimone JM. 2011. PRINT: A novel platform toward shape and size specific nanoparticle theranostics. Acc Chem Res 44: 990-998.

Perumal OP, Inapagolla R, Kannan S, Kannan RM. 2008. The effect of surface functionality on cellular trafficking of dendrimers. Biomaterials 29: 3469-3476.

Qin SH, Geng Y, Discher DE, Yang S. 2006. Temperaturecontrolled assembly and release from polymer vesicles of poly(ethylene oxide)-block-poly( $N$-isopropylacrylamide). Adv Mater 18: 2905.

Qiu Y, Liu Y, Wang L, Xu L, Bai R, Ji Y, Wu X, Zhao Y, Li Y, Chen C. 2010. Surface chemistry and aspect ratio mediated cellular uptake of Au nanorods. Biomaterials 31: 7606-7619.

Ramsden JJ. 1994. Experimental methods for investigating protein adsorption kinetics at surfaces. Q Rev Biophys 27: 41-105.

Rausch K, Reuter A, Fischer K, Schmidt M. 2010. Evaluation of nanoparticle aggregation in human blood serum. Biomacromolecules 11: 2836-2839.

Ray K, Marteyn B, Sansonetti PJ, Tang CM. 2009. Life on the inside: The intracellular lifestyle of cytosolic bacteria. Nat Rev Microbiol 7: 333-340.

Reddy JA, Xu LC, Parker N, Vetzel M, Leamon CP. 2004. Preclinical evaluation of ( $99 \mathrm{~m}$ )Tc-EC20 for imaging folate receptor-positive tumors. J Nucl Med 45: 857-866.

Rejman J, Oberle V, Zuhorn I, Hoekstra AD. 2004. Sizedependent internalization of particles via the pathways of clathrin- and caveolae-mediated endocytosis. Biochem J 377: 159-169.

Ren G, Rudenko G, Ludtke SJ, Deisenhofer J, Chiu W, Pownall HJ. 2010. Model of human low-density lipoprotein and bound receptor based on cryoEM. Proc Natl Acad Sci 107: 1059-1064.

Reynwar BJ, Illya G, Harmandaris VA, Muller MM, Kremer K, Deserno M. 2007. Aggregation and vesiculation of membrane proteins by curvature-mediated interactions. Nature 447: 461-464.

Robbins GP, Jimbo M, Swift J, Therien MJ, Hammer DA, Dmochowski IJ. 2009. Photoinitiated destruction of composite porphyrin-protein polymersomes. J Am Chem Soc 131: 3872-3874.

Rolland JP, Maynor BW, Euliss LE, Exner AE, Denison GM, DeSimone JM. 2005. Direct fabrication and harvesting of monodisperse, shape-specific nanobiomaterials. J Am Chem Soc 127: 10096-10100.

Rothberg KG, Heuser JE, Donzell WC, Ying YS, Glenney JR, Anderson RG. 1992. Caveolin, a protein component of caveolae membrane coats. Cell 68: 673-682.

Sahay G, Alakhova DY, Kabanov AV. 2010. Endocytosis of nanomedicines. J Control Release 145: 182-195.

Sahay G, Querbes W, Alabi C, Eltoukhy A, Zurenko C, Sarkar S, Karagiannis E, Love K, Chen D, Zoncu R, et al. 2013. Efficiency of siRNA delivery by lipid nanoparticles is limited by endocytic recycling. Nat Biotechnol 31: 653-658.

Saini S, Stark DD, Hahn PF, Bousquet JC, Introcasso J, Wittenberg J, Brady TJ, Ferrucci JT Jr. 1987a. Ferrite particles: 
A superparamagnetic MR contrast agent for enhanced detection of liver carcinoma. Radiology 162: 217-222.

Saini S, Stark DD, Hahn PF, Wittenberg J, Brady TJ, Ferrucci JT Jr. 1987b. Ferrite particles: A superparamagnetic MR contrast agent for the reticuloendothelial system. Radiology 162: 211-216.

Sanna V, Sechi M. 2012. Nanoparticle therapeutics for prostate cancer treatment. Nanomedicine 8: S31-S36.

Schmid B, Chung DE, Warnecke A, Fichtner I, Kratz F. 2007. Albumin-binding prodrugs of camptothecin and doxorubicin with an Ala-Leu-Ala-Leu-linker that are cleaved by cathepsin B: Synthesis and antitumor efficacy. Bioconjug Chem 18: 702-716.

Semple SC, Akinc A, Chen J, Sandhu AP, Mui BL, Cho CK, Sah DW, Stebbing D, Crosley EJ, Yaworski E, et al. 2010. Rational design of cationic lipids for siRNA delivery. Nat Biotechnol 28: 172-176.

Shi J, Xiao Z, Kamaly N, Farokhzad OC. 2011. Self-assembled targeted nanoparticles: Evolution of technologies and bench to bedside translation. Acc Chem Res 44: 1123-1134.

Silverstein SB, Rodgers GM. 2004. Parenteral iron therapy options. Am J Hematol 76: 74-78.

Singerman L. 2009. Combination therapy using the small interfering RNA bevasiranib. Retina 29: S49-S50.

Sonawane ND, Szoka FC Jr, Verkman AS. 2003. Chloride accumulation and swelling in endosomes enhances DNA transfer by polyamine-DNA polyplexes. $J$ Biol Chem 278: 44826-44831.

Spinowitz BS, Kausz AT, Baptista J, Noble SD, Sothinathan R, Bernardo MV, Brenner L, Pereira BJ. 2008. Ferumoxytol for treating iron deficiency anemia in CKD. JAm Soc Nephrol 19: 1599-1605.

Stayton PS, Hoffman AS, Murthy N, Lackey C, Cheung C, Tan P, Klumb LA, Chilkoti A, Wilbur FS, Press OW. 2000. Molecular engineering of proteins and polymers for targeting and intracellular delivery of therapeutics. J Control Release 65: 203-220.

Subbarao NK, Parente RA, Szoka FC, Nadasdi L, Pongracz K. 1987. pH-dependent bilayer destabilization by an amphipathic peptide. Biochemistry 26: 2964-2972.

Swanson JA. 2008. Shaping cups into phagosomes and macropinosomes. Nat Rev Mol Cell Biol 9: 639-649.

Symonds P, Murray JC, Hunter AC, Debska G, Szewczyk A, Moghimi SM. 2005. Low and high molecular weight poly(L-lysine)s/poly(L-lysine)-DNA complexes initiate mitochondrial-mediated apoptosis differently. FEBS Lett 579: 6191-6198.

Tabernero J, Shapiro GI, Lorusso PM, Cervantes A, Schwartz GK, Weiss GJ, Paz-Ares L, Cho DC, Infante JR, Alsina M, et al. 2013. First-in-humans trial of an RNA interference therapeutic targeting VEGF and KSP in cancer patients with liver involvement. Cancer Discov 3: 406-417.

Takamori S, Holt M, Stenius K, Lemke EA, Gronborg M, Riedel D, Urlaub H, Schenck S, Brugger B, Ringler P, et al. 2006. Molecular anatomy of a trafficking organelle. Cell 127: $831-846$.

Tanaka T, Fujishima Y, Kaneo Y. 2001. Receptor mediated endocytosis and cytotoxicity of transferrin-mitomycin $C$ conjugate in the HepG2 cell and primary cultured rat hepatocyte. Biol Pharm Bull 24: 268-273.
Thurn KT, Arora H, Paunesku T, Wu A, Brown EM, Doty C, Kremer J, Woloschak G. 2011. Endocytosis of titanium dioxide nanoparticles in prostate cancer PC-3M cells. Nanomedicine 7: 123-130.

Torchilin V. 2011. Tumor delivery of macromolecular drugs based on the EPR effect. Adv Drug Deliv Rev 63: 131-135.

Tsai B. 2007. Penetration of nonenveloped viruses into the cytoplasm. Ann Rev Cell Dev Biol 23: 23-43.

Tzlil S, Deserno M, Gelbart WM, Ben-Shaul A. 2004. A statistical-thermodynamic model of viral budding. Biophysical J 86: 2037-2048.

Vaishnaw AK, Gollob J, Gamba-Vitalo C, Hutabarat R, Sah D, Meyers R, de Fougerolles T, Maraganore J. 2010. A status report on RNAi therapeutics. Silence 1: 14.

Vazquez-Calvo A, Saiz JC, McCullough KC, Sobrino F, Martin-Acebes MA. 2012. Acid-dependent viral entry. Virus Res 167: 125-137.

Veesler D, Johnson JE. 2012. Virus maturation. Ann Rev Biophys 41: 473-496.

Vercauteren D, Vandenbroucke RE, Jones AT, Rejman J, Demeester J, De Smedt SC, Sanders NN, Braeckmans K. 2010. The use of inhibitors to study endocytic pathways of gene carriers: Optimization and pitfalls. Mol Ther 18: 561-569.

Vercauteren D, Piest M, van der Aa LJ, Al Soraj M, Jones AT, Engbersen JF, De Smedt SC, Braeckmans K. 2011. Flotillin-dependent endocytosis and a phagocytosis-like mechanism for cellular internalization of disulfide-based poly(amidoamine)/DNA polyplexes. Biomaterials 32: 3072-3084.

Verma A, Uzun O, Hu Y, Han HS, Watson N, Chen S, Irvine DJ, Stellacci F. 2008. Surface-structure-regulated cellmembrane penetration by monolayer-protected nanoparticles. Nat Mater 7: 588-595.

Verma S, Miles D, Gianni L, Krop IE, Welslau M, Baselga J, Pegram M, Oh DY, Dieras V, Guardino E, et al. 2012 Trastuzumab emtansine for HER2-positive advanced breast cancer. N Engl J Med 367: 1783-1791.

Vonarbourg A, Passirani C, Saulnier P, Benoit J-P. 2006. Parameters influencing the stealthiness of colloidal drug delivery systems. Biomaterials 27: 4356-4373.

Wadia JS, Stan RV, Dowdy SF. 2004. Transducible TAT-HA fusogenic peptide enhances escape of TAT-fusion proteins after lipid raft macropinocytosis. Nat Med 10: $310-315$.

Wagner E, Plank C, Zatloukal K, Cotten M, Birnstiel ML. 1992. Influenza-virus hemagglutinin-Ha-2 N-terminal fusogenic peptides augment gene-transfer by transferrin polylysine DNA complexes: Toward a synthetic virus-like gene-transfer vehicle. Proc Natl Acad Sci 89: 7934-7938.

Wahlgren M, Arnebrant T. 1991. Protein adsorption to solid surfaces. Trends Biotechnol 9: 201-208.

Wang Z, Tiruppathi C, Minshall RD, Malik AB. 2009. Size and dynamics of caveolae studied using nanoparticles in living endothelial cells. ACS Nano 3: 4110-4116.

Wasylewski Z, Stryjewski W, Wasniowska A, Potempa J, Baran K. 1986. Effect of calcium binding on conformational changes of staphylococcal metalloproteinase measured by means of intrinsic protein fluorescence. Biochim Biophys Acta 871: 177-181. 
A. Akinc and G. Battaglia

Weissleder R, Hahn PF, Stark DD, Rummeny E, Saini S Wittenberg J, Ferrucci JT. 1987. MR imaging of splenic metastases: Ferrite-enhanced detection in rats. AJR Am J Roentgenol 149: 723-726.

Wiethoff CM, Wodrich H, Gerace L, Nemerow GR. 2005 . Adenovirus protein VI mediates membrane disruption following capsid disassembly. J Virol 79: 1992-2000.

Witzig TE, Gordon LI, Cabanillas F, Czuczman MS, Emmanouilides C, Joyce R, Pohlman BL, Bartlett NL, Wiseman GA, Padre N, et al. 2002. Randomized controlled trial of yttrium-90-labeled ibritumomab tiuxetan radioimmunotherapy versus rituximab immunotherapy for patients with relapsed or refractory low-grade, follicular, or transformed B-cell non-Hodgkin's lymphoma. J Clin Oncol 20: $2453-2463$.

Wyman TB, Nicol F, Zelphati O, Scaria PV, Plank C, Szoka FC. 1997. Design, synthesis, and characterization of a cationic peptide that binds to nucleic acids and permeabilizes bilayers. Biochemistry 36: 3008-3017.

Xia T, Kovochich M, Brant J, Hotze M, Sempf J, Oberley T, Sioutas C, Yeh JI, Wiesner MR, Nel AE. 2006. Comparison of the abilities of ambient and manufactured nanoparticles to induce cellular toxicity according to an oxidative stress paradigm. Nano Lett 6: 1794-1807.

Xia T, Kovochich M, Liong M, Zink JI, Nel AE. 2008. Cationic polystyrene nanosphere toxicity depends on cellspecific endocytic and mitochondrial injury pathways. ACS Nano 2: 85-96.

Yee J, Besarab A. 2002. Iron sucrose: The oldest iron therapy becomes new. Am J Kidney Dis 40: 1111-1121.

Yi X, Shi X, Gao H. 2011. Cellular uptake of elastic nanoparticles. Phys Rev Lett 107: 098101.
Yla-Herttuala S. 2012. Endgame: Glybera finally recommended for approval as the first gene therapy drug in the European union. Mol Ther 20: 1831-1832.

Younes A, Bartlett NL, Leonard JP, Kennedy DA, Lynch CM, Sievers EL, Forero-Torres A. 2010. Brentuximab vedotin (SGN-35) for relapsed CD30-positive lymphomas. N Engl J Med 363: 1812-1821.

Yuan H, Li J, Bao G, Zhang S. 2010. Variable nanoparticlecell adhesion strength regulates cellular uptake. Phys Rev Lett 105: 138101.

Zalipsky S, Hansen CB, Oaks JM, Allen TM. 1996. Evaluation of blood clearance rates and biodistribution of poly(2-oxazoline)-grafted liposomes. J Pharm Sci 85: $133-137$.

Zeng F, Lee H, Allen C. 2006. Epidermal growth factorconjugated poly(ethylene glycol)-block-poly( $\delta$-valerolactone) copolymer micelles for targeted delivery of chemotherapeutics. Bioconjug Chem 17: 399-409.

Zhang Z, Huey Lee S, Feng SS. 2007. Folate-decorated poly(lactide-co-glycolide)-vitamin E TPGS nanoparticles for targeted drug delivery. Biomaterials 28: 1889-1899.

Zhang S, Li J, Lykotrafitis G, Bao G, Suresh S. 2009. Sizedependent endocytosis of nanoparticles. Adv Mater 21: 419-424.

Zimmerberg J, Kozlov MM. 2006. How proteins produce cellular membrane curvature. Nat Rev Mol Cell Biol 7: 9-19.

Zimmermann TS, Lee AC, Akinc A, Bramlage B, Bumcrot D, Fedoruk MN, Harborth J, Heyes JA, Jeffs LB, John M, et al. 2006. RNAi-mediated gene silencing in non-human primates. Nature 441: 111-114. 


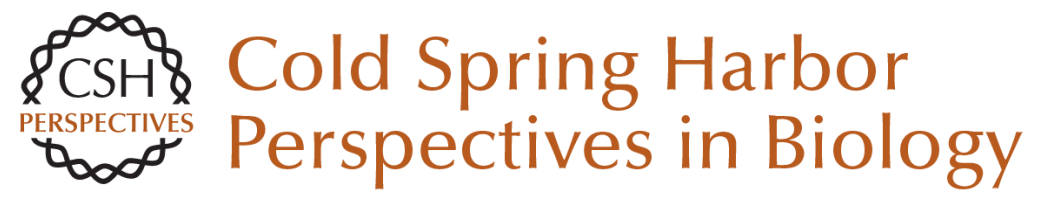

\title{
Exploiting Endocytosis for Nanomedicines
}

\author{
Akin Akinc and Giuseppe Battaglia \\ Cold Spring Harb Perspect Biol 2013; doi: 10.1101/cshperspect.a016980
}

\section{Subject Collection Endocytosis}

\section{Endocytosis: Past, Present, and Future Sandra L. Schmid, Alexander Sorkin and Marino Zerial}

Rab Proteins and the Compartmentalization of the Endosomal System Angela Wandinger-Ness and Marino Zerial

Cargo Sorting in the Endocytic Pathway: A Key Regulator of Cell Polarity and Tissue Dynamics Suzanne Eaton and Fernando Martin-Belmonte

Unconventional Functions for Clathrin, ESCRTs, and Other Endocytic Regulators in the Cytoskeleton, Cell Cycle, Nucleus, and Beyond: Links to Human Disease

Frances M. Brodsky, R. Thomas Sosa, Joel A. Ybe, et al.

Endocytosis of Viruses and Bacteria Pascale Cossart and Ari Helenius

Lysosomal Adaptation: How the Lysosome

\section{Responds to External Cues} Carmine Settembre and Andrea Ballabio

Reciprocal Regulation of Endocytosis and Metabolism

Costin N. Antonescu, Timothy E. McGraw and Amira Klip

Endocytosis and Autophagy: Exploitation or Cooperation?

Sharon A. Tooze, Adi Abada and Zvulun Elazar
Imaging and Modeling the Dynamics of

Clathrin-Mediated Endocytosis

Marcel Mettlen and Gaudenz Danuser

Endocytic Accessory Factors and Regulation of

Clathrin-Mediated Endocytosis

Christien J. Merrifield and Marko Kaksonen

The Complex Ultrastructure of the Endolysosomal

System Judith Klumperman and Graça Raposo

The Biogenesis of Lysosomes and

Lysosome-Related Organelles J. Paul Luzio, Yvonne Hackmann, Nele M.G. Dieckmann, et al.

Endocytosis, Signaling, and Beyond Pier Paolo Di Fiore and Mark von Zastrow

Clathrin-Independent Pathways of Endocytosis Satyajit Mayor, Robert G. Parton and Julie G. Donaldson

The Role of Endocytosis during Morphogenetic Signaling Marcos Gonzalez-Gaitan and Frank Jülicher

Role of Endosomes and Lysosomes in Human Disease

Frederick R. Maxfield

For additional articles in this collection, see http://cshperspectives.cshlp.org/cgi/collection/

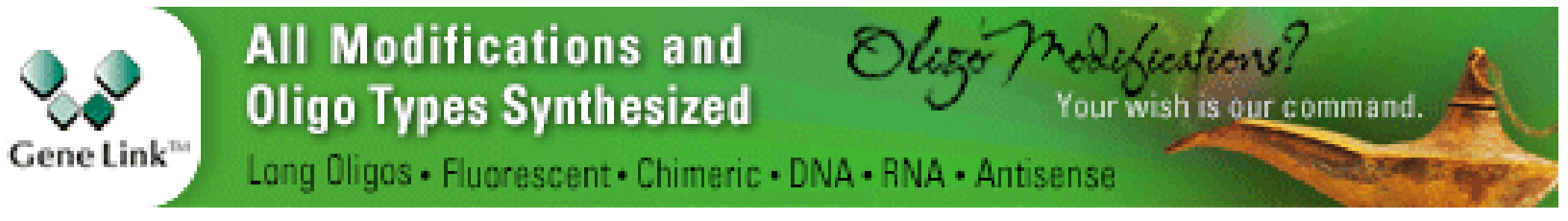


For additional articles in this collection, see http://cshperspectives.cshlp.org/cgi/collection/

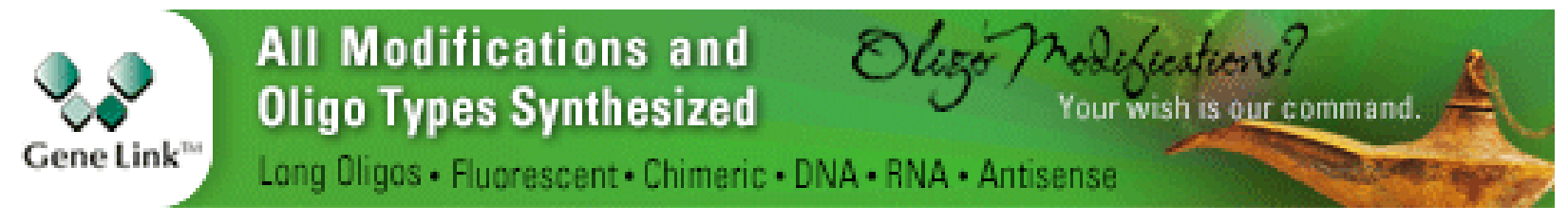

Copyright @ 2013 Cold Spring Harbor Laboratory Press; all rights reserved 